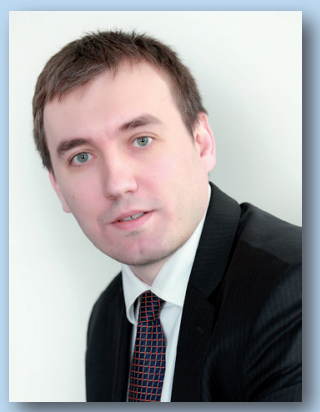

mr Petar Kasavica

Erste Bank ad Beograd petar.kasavica@erstebank.rs
Rad primljen: 02.11.2013. Odobren za štampu: 15.04 .2014

\section{FINANSIRANJE LANCA SNABDEVANJA}

\section{Rezime}

Koncept finansiranja lanca snabdevanja (supply chain finance) predstavlja odgovor na globalnu nelikvidnost, intenziviranu svetskom ekonomskom krizom i globalizaciju poslovnih i finansijskih tokova. Rastuća nelikvidnost urušava kreditne rejtinge privrednih subjekata smanjujući potencijale ostvarivanja projektovanih ciljeva (profitabilnost i kvalitet portfolija). Kako bi to prevazišle banke uvode proizvode koji su fleksibilni zahtevima specifičnih transakcija. Predmetni proizvodi prenose fokus sa kreditnog rejtinga i rizika klijenta na kreditni rejting i rizik poslovnog partnera (kupca) donoseći benefite svim učesnicima transakcije („win-win-win“). Takođe, aktivnosti su usmerene ka analizi transakcije, tj. izolaciji i zaštiti novčanog toka kao izvora otplate finansijskog instrumenta. S druge strane sve više su zastupljene transakcije bazirane na riziku poslovne banke klijentovog poslovnog partnera ili pak riziku instrumenta obezbeđenja (zalihe). Fokus je upravo na finansiranju adekvatnih faza lanca snabdevanja, jer je dokazano da je upravljanje odnosom sa poslovnim partnerom ključno za efikasno upravljanje sopstvenim poslovanjem. Na tenzijama koje postoje u odnosima između partnera (sve duži rokovi plaćanja), nastaje koncept finansiranja lanca snabdevanja. Odluke banaka su bazirane na celokupnom lancu snabdevanja (široka informaciona osnova) pomerajući fokus sa proizvoda (zastupljeno pre krize) na potrebu klijenta. Na taj način odluke postaju sveobuhvatnije, brže, i preciznije, a portfolio manje rizičan. Preko individualnog portfolija banaka i tržište nacionalnih ekonomija postaje sigurnije i likvidnije. U pitanju su veoma profitabilne transakcije jer transferom rizika omogućavaju finansiranje preduzeća kojima klasično kreditiranje u najvećem broju slučajeva nije dostupno.

Ključne reči: finansiranje lanca snabdevanja, strukturirano finansiranje trgovine, faktoring, obrnuti faktoring

JEL: D22, G21, L23, O31 


\section{SUPPLY \\ CHAIN FINANCE}

\section{Summary}

The concept of supply chain finance is a response to global illiquidity, intensified through the global economic crisis and globalization of commercial and financial flows. The growing illiquidity undermines credit ratings of economic entities, thereby reducing the potential for achieving the projected goals (profitability and portfolio quality). In order to overcome this, banks have introduced certain products flexible to the requirements of specific transactions. The concerned products redirect the focus from a client's credit rating and risk to the credit rating and risk of a business partner (buyer), resulting in benefits for all transaction participants ("win-win-win"). Moreover, the activities are targeted at transaction analysis, i.e. the isolation and protection of the cash flow as the source of financial instrument's repayment. On the other hand, there has been an increasing number of transactions based on the risk of the commercial bank of the client's business partner, or on the risk of collateral (inventory). The focus is actually placed on the financing of adequate supply chain stages, given that counterparty relationship management has been proven to be crucial for efficient management of one's own business. The tensions existing in the relations between partners (increasingly long payment deadlines) are in the basis of the supply chain finance concept. Decisions made by banks are based on the entire supply chain (wide information basis), thereby shifting the focus from the product (as was the case before the crisis) to the client's needs. Thus, decisions become increasingly comprehensive, quicker, and more precise, and portfolios less risky. Through the individual portfolio of banks, the market of national economies also becomes safer and more liquid. These are rather profitable transactions, because, due to the risk transfer, financing is enabled to companies to whom classic crediting in most cases is not available.

Keywords: supply chain finance, structured trade finance, factoring, reverse factoring 


\section{Pojam lanca snabdevanja i koncept finansiranja lanca snabdevanja}

Lanac snabdevanja (supply chain) predstavlja mrežu organizacija uključenih različitim vezama $\mathrm{u}$ različite procese $\mathrm{i}$ aktivnosti koje proizvode vrednost $\mathrm{u}$ vidu proizvoda i usluga usmerenih ka zadovoljenju potreba krajnjeg korisnika ili potrošača. Takođe, predstavlja i ukupni tok materijala, informacija i novca od dobavljačevog dobavljača kroz preduzeće, pa sve do kupčevih kupaca. Lanac snabdevanja predstavlja i asocijaciju pojedinačnih, različitih poslovnih aktivnosti više privrednih subjekata. Troškovi poslovanja su manji, a konkurentnost proizvoda veća u slučaju preduzeća uključenih $\mathrm{u}$ lanac snabdevanja $\mathrm{u}$ odnosu na samostalno poslovanje bez ikakve povezanosti i razumevanja međusobnih poslovnih potreba. ${ }^{1}$ Lanac snabdevanja je ukupni tok materijala, informacija i novca od dobavljačevog dobavljača kroz preduzeće, pa sve do kupčevih kupaca. ${ }^{2}$ Finansiranje lanca snabdevanja predstavlja mladu poslovnu filozofiju koja se razvila u poslednjih 30 godina i koja podrazumeva korišćenje finansijskih instrumenata, poslovnog iskustva, prakse i savremenih tehnoloških rešenja kako bi se obrtna imovina različitih ciklusa poslovanja (nabavka, proizvodnja, prodaja, itd.) brže pretvarala u gotovinu, ubrzao operativni novčani tok i poboljšalo upravljanje likvidnošću poslovnih partnera koji sarađuju na dugoročnoj osnovi (prodavaca i kupaca, ali i preduzeća koja se nalaze između njih u okviru lanca snabdevanja). ${ }^{3}$ Polazna osnova banke jeste sagledavanje poslovnih potreba sopstvenog klijenta, ali i njegovih poslovnih partnera uz težnju da se detaljnije pronikne $u$ analizu odnosa u lancu snabdevanja, kako bi se obezbedio model finansiranja pod kojim bi novčani tok kao rezultat finansiranja bio izvor otplate odobrenog instrumenta finansiranja. Cilj finansiranja lanca snabdevanja, a znajući da on pokriva protok robe i protok novca jeste smanjivanje vremenskog "gap-a" koji postoji između protoka robe i protoka novca. Cilj finansiranja je postizanje bolje novčane prohodnosti lanca snabdevanja.

Iako se radi o novom poglavlju bankarskog poslovanja koje se nalazi pod okriljem finansiranja trgovine (trade finance), koncept finansiranja lanca snabdevanja pruža mogućnost pomeranja fokusa banke sa finansiranja određenih delova ukupnih potreba klijenata (likvidnost, obrtni kapital, stalna imovina itd.) na finansiranje celokupnog lanca snabdevanja. To je značajno i za kvalitet portfolija banke, jer su odluke zasnovane na razumevanju klijentovih potreba, ali i potreba njegovih poslovnih partnera. Informacije na kojima se baziraju odluke su sveobuhvatnije, te su i same odluke brže, kvalitetnije i preciznije. Dugo vremena je ovaj oblik saradnje banke, kupca i dobavljača bio zanemarivan u korist klasičnog kreditiranja i posmatran više kao teoretska opcija. U današnje vreme, kada su se pravila tržišta promenila uz globalizaciju poslovnih i finansijskih tokova i svetsku ekonomsku krizu, kada postoji novo okruženje u kojem banke više ne mogu lako da odobravaju kredite usled rastuće nelikvidnosti koja urušava kreditne rejtinge poslovnih subjekata, koncept finansiranja lanca snabdevanja dobija sve više na značaju. Radi se o modelu finansiranja koji omogućava bankama da prilagode svoju ponudu sa rastućim potrebama klijenata u domenu lanca snabdevanja. Dakle, od tradicionalne orijentacije ka proizvodu, banke pomeraju interes na veću saradnju sa svojim klijentima i klijentima svojih klijenata, a kako bi ih snabdele rešenjima koja su krojena prirodi njihovih potreba. ${ }^{4}$ Fokus sa proizvoda se pomera na potrebu klijenta, što je u suštini nova poslovna filozofija usmerena ka kreiranju manje rizičnog, ali i visoko profitabilnog portfolija. Hiperprodukcija rešenja koja nisu u najboljoj meri prilagođena potrebama klijenata kako bi se ostvarili planovi više nije primarna imajući u vidu posledice krize i veliki broj klijenata koje

1 Regodić, Dušan, "Menadžment snabdevanjem", Univerzitet Singidunum, Beograd, 2008, str. 37 S tim u vezi treba napomenuti da Evropa sistematski podstiče primenu preciznog računanja vremena - Exact/Exact ili Atual/Actual, ili pak primenu japanskog načina - Actual/365.

2 Ahmad, Munir \& Benson, Roger "Benchmarking in the Process Industries", IChemE 2000, (izvor: http://www.clermiston. com.au/Supply\%20Chain.htm)

3 Bryant,Charles and Camerinelli, Enrico, EBA (Euro Banking Association), "Supply chain finance“, 2012

4 Carswell, Kitt, Product Manager and Executive Consultant within CGI's Trade Services Group, "Supply Chain Finance: A new way for trade banks to strengthen customer relationships", 2007, p. 8 


\section{Supply Chain and the Concept of Supply Chain Finance}

Supply chain is a network of organizations in different ways involved in various processes and activities generating value in form of products and services aimed at satisfying the needs of ultimate beneficiaries or consumers. Supply chain is an association of different, individual business activities of several economic entities. Operating costs are lower, and the product's competitiveness higher in case of enterprises grouped within the supply chain, compared to independent operation with no connection whatsoever or any understanding of mutual business needs ${ }^{1}$.Supply chain is the total flow of materials, information and cash from the suppliers' suppliers, right through an enterprise, to the customers' customers'. Supply chain finance is a young business philosophy developed in the last 30 years, implying the usage of financial instruments, business experience, practice and modern technological solutions in order to convert the working assets in different business cycles (procurement, production, sales, etc.) into cash more quickly; in order to accelerate the operating cash flow; and improve liquidity management of longterm business partners (sellers and buyers, but also enterprises which are in between them within the supply chain) ${ }^{3}$. The starting point of a bank is to consider the business requirements of its own clients, but also of their business partners, with the objective of getting deep into the analysis of supply chain relations, in order to provide a financing model that would enable a cash flow, as the result of financing, to be the source of repayment of the granted instrument of finance. The goal of supply chain finance, bearing in mind that it covers both the flow of goods and flow of cash, is to reduce the time gap existing between the flow of goods and flow of cash. The objective of financing is to achieve better cash mobility within the supply chain.
Although this is a new chapter in banking which falls under the category of trade finance, the concept of supply chain finance offers the possibility to shift the bank's focus from financing certain segments of total client's needs (liquidity, working capital, fixed assets, etc.) to the financing of the entire supply chain. This is also significant for the bank's portfolio quality, given that its decisions are based on understanding the client's needs, but also the needs of his business partners. Information on which decisions are based is more comprehensive, thus increasing the swiftness, quality and precision of decisions themselves. For a long time this form of cooperation between banks, customers and suppliers has been neglected in favor of classic lending, being considered as more of a theoretical option. Today, when the market rules have changed in parallel with the globalization of commercial and financial flows and the global economic crisis, when there has been this new environment in which banks can no longer grant loans that easily due to the growing illiquidity undermining credit ratings of commercial entities, the concept of supply chain finance has been gaining on importance. It is a model of finance enabling banks to adjust their offer to the growing needs of their clients within the supply chain. In other words, from their traditional product-orientation, banks have shifted their interest towards the more intense cooperation with their clients and their clients' clients, in order to provide them with solutions tailored to meet their needs ${ }^{4}$.The focus has shifted from a product to the client's needs, which is essentially a new business philosophy, aimed at creating a less risky, yet highly profitable portfolio. Hyperproduction of solutions which are not best suited to the client's needs, in order to execute one's plans, is no longer the priority, bearing in mind the consequences of the crisis and the large number of clients pushed into the position of general illiquidity and bankruptcy owing to such attitude of banks.

1 Regodić, Dušan, “Menadžment snabdevanjem”, Univerzitet Singidunum, Beograd, 2008, str. 37

2 Ahmad, Munir \& Benson, Roger "Benchmarking in the Process Industries", IChemE 2000, (izvor: http://www.clermiston. com.au/Supply\%20Chain.htm)

3 Bryant,Charles and Camerinelli, Enrico, EBA (Euro Banking Association), "Supply chain finance“, 2012

4 Carswell, Kitt, Product Manager and Executive Consultant within CGI's Trade Services Group, "Supply Chain Finance: A new way for trade banks to strengthen customer relationships", 2007, p. 8 
je takav odnos banaka doveo u poziciju opšte nelikvidnosti i bankrotstva.

\section{Potreba i generisanje tražnje za proizvodima pod okriljem koncepta finansiranja lanca snabdevanja}

Potreba za proizvodima pod okriljem koncepta finansiranja lanca snabdevanja je sve izraženija. Naime, danas kupci nisu u mogućnosti da predvide kada će dobavljač isporučiti proizvod, ali i kada će od trenutka isporuke, tj. potvrde (konfirmacije) isporuke, a nakon kontrole dostavljenih proizvoda i pratećih faktura, potraživanje dospeti na plaćanje (odloženi rok plaćanja uz prijem proizvoda i relevantne fakture). To je razlog zašto je sa stanovišta kupca nemoguće precizno projektovati novčane tokove. U trenutku kada kupac primi proizvode sa fakturama, neophodno je pregledati fakture i ustanoviti da li se podudaraju sa narudžbenicama, a zatim i izvršiti fizičku kontrolu proizvoda. Kada se ustanovi da su opisane kontrole proizvele pozitivan rezultat, može se pristupiti overi i internom zavođenju faktura, a to je momenat od koga počinje da teče rok za odloženo plaćanje. Predviđanje rokova je teško iz razloga što mnogi prodavci imaju sve više likvidnosnih problema što rađa neizvesnost $\mathrm{u}$ njihovim poslovnim ciklusima, a da bi isporučili robu moraju prvo da je proizvedu ili da je kupe. Takođe, rizik koji se pojavljuje, pored rizika interne ne-efikasnosti, lošeg fakturisanja ili kvaliteta robe i likvidnosti prodavca, jeste rizik prostorne udaljenosti prodavca i kupca koji dovodi do rizika transporta, kako sa stanovišta vremenskog perioda, tako i sa stanovišta rizika oštećenja robe. Svi pobrojani rizici se ispoljavaju kroz dva ključna rizika, a to je produženje rokova naplate sa stanovišta dobavljača i plaćanja sa stanovišta kupca, što proizvodi rizik nemogućnosti planiranja novčanih tokova svih učesnika na tržištu. Pored nedostatka kreditnih sredstava zbog nelikvidnosti tržišnih učesnika i nemogućnosti plasiranja sredstava usred promenjenih poslovnih politika banaka, rizik planiranja novčanih tokova dovodi do ciklične nelikvidnosti privreda pojedinačnih zemalja prelivajući negativne efekte i na globalno tržište. Kako bi kompenzovali rizike vremenskih rokova kupci teže da skladište veći nivo zaliha u odnosu na kapacitete proizvodnje ili potencijale tržišta. Držanje većeg nivoa zaliha na skladištu proizvodi veće troškove držanja zaliha, duže angažovanje novca u njima i sporiji obrt zaliha koji usporava kako operativni ciklus (prosečan period naplate potraživanja od kupaca + prosečan period držanja zaliha), tako i novčani tok (operativni ciklus - prosečan period plaćanja obaveza dobavljačima). S druge strane, kako bi opstali i izmirivali tekuće obaveze, kupci moraju i da imaju dovoljno adekvatan i stabilan priliv sredstava od prodaje. Nelikvidnost koja je sveprisutnija i lokalno i globalno negativno deluje na predvidivost ovih tokova, ali i produžava rokove naplate. Dakle, kupcima njihovi kupci plaćaju na duže rokove. Kako bi duži obrt zaliha i potraživanja kompenzovali, tj. skratili novčani tok, kupci vrše pritisak na dobavljače da i oni produže sopstvene rokove naplate. Pritisak može biti zasnovan na jednostranoj odluci kupca da "probija” valute plaćanja prema dobavljaču što urušava poslovni ciklus dobavljača, ali i saradnju i kao krajnju konsekvencu dovodi do preusmeravanja isporuka na druge kupce. Ukoliko se pak produženje rokova zasniva na dogovoru između kupca i dobavljača, kupac mora da ponudi nešto kao kontra-uslugu, a to može da dovede ili do veće cene isporuka (smanjuje profit kupca), ili pak preuzimanja većih kontigenata robe $\mathrm{u}$ odnosu na kapacitete ili tržište. Dakle, pored negativnog ambijenta za kupce, udar na dobavljače je konsekvetno negativan. Dobavljači u Srbiji u proseku čekaju preko 120 dana (podatak NBS - u praksi i mnogo više) da naplate potraživanje što kao krajnju konsekvencu rađa nestabilnu i rizičnu bazu snabdevanja. Dakle, imamo nestabilno i rizično plaćanje s jedne strane, a s druge strane nestabilno i rizično snabdevanje. Pod uticajem svetske ekonomske krize lanac se nastavlja i konsekventno pogađa sve tržišne igrače, a rokovi i rizici se konstantno povećavaju. $\mathrm{Na}$ prethodno opisanim osnovama nastaje potreba za finansiranjem lanca snabdevanja kao osnove za prevazilaženje problema i tenzija koji postoje između prodavaca sa jedne strane i kupaca sa druge strane. Jedna od posebnih prednosti određenih proizvoda koncepta finansiranja lanca snabdevanja jeste obezbeđivanje koristi za sve učesnike (banka, prodavac i kupac). 


\section{Demand for Products and How to Generate it within Supply Chain Finance}

Demand for products within the concept of supply chain finance has been increasingly prominent. Namely, today's consumers are in no position to predict when the supplier will deliver the product, or when, starting from the moment of delivery, i.e. the confirmation of delivery, following the control of delivered products and accompanying invoices, the receivable will mature for payment (deferred payment after the receipt of products and relevant invoices). This is why, from the consumer's perspective, it is impossible to project cash flow in a precise manner. Upon receiving the products with the invoices, the consumer must examine these invoices and establish whether there are any discrepancies compared with the purchase orders, after which he must perform the physical control of the concerned products. Once it is established that the described controls have yielded a positive result, one can start the validation process and internal registration of invoices, which marks the commencement of the deferred payment deadline term. Predicting the deadlines is difficult because many sellers increasingly face liquidity problems, generating uncertainty in their business cycles, and in order to deliver the goods they first have to produce them or purchase them. Moreover, the risk which occurs in addition to the risk of internal inefficiency, poor invoicing or quality of goods and the seller's liquidity is the risk of spatial distance between the seller and the buyer, incurring the risk of transport, both in terms of time period, and in terms of potential damage inflicted to the goods. All the above listed risks are manifested in two key risks, i.e. extension of collection deadlines from the supplier's perspective, and extension of payment deadlines from the buyer's perspective, generating the risk of inability to plan cash flows for all market participants. In addition to the lack of credit funds due to the illiquidity of market participants and inability to place funds due to the amended business policies of banks, the risk of cash flow management leads to the cyclical illiquidity of certain countries' economies, spilling the negative effects onto the global market as well. With a view to compensating the risks of time deadlines, the buyers tend to store more inventories in relation to production capacities or market potentials. Storing more inventories in the warehouse generates higher costs of carry, longer deployment of cash in respect of inventories, and slower turnover of inventories, which then slows down both the operational cycle (average period of collection of receivables from buyers + average period of storing inventories), and the cash flow (operational cycle - average period of payment of liabilities to suppliers). On the other hand, in order to survive and settle their current liabilities, buyers must have a sufficiently adequate and stable inflow of funds from sale. Illiquidity, becoming increasingly present both locally and globally, has an adverse effect on predictability of these flows, but also prolongs collection deadlines. Thus, the buyers get paid by their buyers after longer periods of time. Wishing to compensate the longer turnover of inventories and receivables, i.e. to shorten the cash flow, the buyers pressure the suppliers to make them prolong their own collection deadlines. The pressure can be based on a unilateral decision of the buyer to "break" the payment value date towards the supplier which undermines the supplier's business cycle, but also their cooperation in general, ultimately leading to delivery being redirected to other buyers. If, however, the extension of deadlines is based on the agreement between the buyer and supplier, the buyer has to offer something as a counter-service, which may cause either a higher price of delivery (reducing the buyer's profit), or the purchase of bigger batches of goods in relation to the capacities or the market. Thus, in addition to the environment being negative for buyers, the shock for suppliers is consequently negative as well. Suppliers in Serbia, on average, wait over 120 days (NBS data - in practice, this is much longer) to collect the receivables, which ultimately generates an unstable and risky supply basis. Therefore, there is unstable and risky payment, on the one side, and unstable and risky supply on the other side. Under the influence of the global economic crisis, the string of events goes on, consequently affecting all market players, with 


\section{Važnost koncepta finansiranja lanca snabdevanja za banke}

\section{Tradicionalna kreditna podrška kao bazična} aktivnost banke zastareva i ne donosi dovoljne benefite klijentu i banci. Drugim rečima, kao struktura finansiranja u izmenjenim uslovima poslovanja (kriza likvidnosti) nije najadekvatnije prilagođena potrebama klijenta i banke. Takođe, klijenti su tokom trenutne ekonomske krize suočeni sa teškoćama povodom pristupa sredstvima finansiranja kroz klasično kreditiranje. Koncept finansiranja lanca snabdevanja omogućava bankama da finansiraju klijente na osnovu izolovanog novčanog toka, pa i na kreditnom bonitetu snažnog kupca (obrnuti faktoring). Banka na taj način ima prednost $u$ relativno nerizičnom plasmanu prema klijentu koji drugačije eksterno finansiranje ne bi mogao da dobije. Naravno, ovakav vid finansiranja doprinosi i porastu profitabilnosti banke. ${ }^{5}$

Primenom različitih tehnika upravljanja lancima snabdevanja, preduzeća unapređuju likvidnost (smanjuju "gap-ove" između fizičkog protoka robe i protoka novca), a to predstavlja oblast gde poslovne banke usled većeg interesovanja klijenata mogu da traže sopstvene interese i benefite. Dakle, preduzeća sprovode razne oblike poboljšanja efikasnosti lanca snabdevanja i poznaju problematiku oblasti, dok banke mogu da ponude nova rešenja $u$ vidu različitih proizvoda finansiranja lanca snabdevanja.

Koncept finansiranja lanca snabdevanja je povezan sa protokom robe i novca i svojim rešenjima pomaže klijentima da smanje zalihe, da poboljšaju poštovanje rokova proizvodnje, da bolje upravljaju potraživanjima i obavezama. To definitivno omogućava manje i češće nabavke u odnosu na jednu ili par velikih, čime se utiče na smanjenje rizika i bolju novčanu prohodnost lanca snabdevanja. Na taj način se ubrzava ciklus gotovine. Banka kroz određeni proizvod finansiranja lanca snabdevanja podstiče ne samo izolaciju novčanog toka za otplatu sopstvene izloženosti, već isti ubrzava i unapređuje na široj osnovi.

$\mathrm{U}$ trenutnoj recesiji, inovacije po pitanju proizvoda i fleksibilnost u pristupu klijentovim potrebama stvaraju nove atraktivne mogućnosti finansiranja, otvarajući bankama šanse za profitom, kao i pozicijom u kojoj su više nego ikada orijentisane ka klijentima. Stvara se veoma tesna veza kojom se klijent dugoročno veže za banku. S druge strane radi se o proizvodima koji nisu rizični kao klasičan kreditni aranžman. Dakle, dobrom strukturom transakcije banke pronalaze najbolji proizvod, dugoročno vezuju klijenta za sebe uz veoma profitabilan i siguran aranžman. $^{6}$

Klijenti da bi optimizirali obrtni kapital i ubrzali ciklus gotovine primenjuju različite tehnike upravljanja lancom snabdevanja. Veoma često koriste kapital iz operativnog poslovanja kako bi ga uložili u različite segmente koji kontrolišu i podstiču efikasnost lanca snabdevanja (logistika nabavke, prodaje, nove mašine i oprema, itd.), što narušava tekuću likvidnost. Ukoliko im banka ponudi sopstveno rešenje $u$ vidu adekvatnog finansijskog instrumenta klijenti mogu sačuvati likvidnost i poboljšati efikasnost lanca snabdevanja.

\section{Varijacije proizvoda koncepta finansiranja lanca snabdevanja}

- finansiranje faze pre isporuke (pre-shipment finance) - finansiranje bazirano na zalihama uz prijem skladišnica kao instrumenta obezbeđenja, na osnovu naloga za kupovinu ili na osnovu preuzimanja obaveze za plaćanje druge institucije po osnovu naloga za kupovinu.

- finansiranje $\mathrm{u}$ toku isporuke (shipment finance) - diskontovanje izvoznog akreditiva.

- finansiranje faze nakon isporuke (postshipment finance) - finansiranje bazirano na potraživanjima prema kupcima - otkup potraživanja, eskont menica, faktoring i obrnuti faktoring. ${ }^{7}$

- strukturno finansiranje trgovine (structured

5 Carswell, Kitt, Product Manager and Executive Consultant within CGI's Trade Services Group, “Supply Chain Finance: A new way for trade banks to strengthen customer relationships", 2007, p. 10

6 Bryant,Charles and Camerinelli, Enrico, EBA (Euro Banking Association), "Supply chain finance“, 2012, p. 18

7 Carswell, Kitt, Product Manager and Executive Consultant within CGI's Trade Services Group, "Supply Chain Finance: A new way for trade banks to strengthen customer relationships", 2007, p. 7 
the deadlines and risks being constantly on the increase. The above described foundations generate the necessity for supply chain finance as the basis for overcoming the problems and tensions existing between sellers, on the one hand, and consumers, on the other. One of the particular advantages of certain products within the concept of supply chain finance is that it secures benefits for all stakeholders (bank, seller and buyer).

\section{Importance of Supply Chain Finance for Banks}

The traditional credit support as the basic bank's activity has been outdated, and does not yield sufficient benefits to the client and the bank. In other words, the structure of finance in the altered business conditions (liquidity crisis) is not adequately adjusted to the needs of the client and the bank. Furthermore, during the current economic crisis the clients are facing difficulties when it comes to accessing finance through classic crediting. The concept of supply chain finance enables banks to finance their clients based on an isolated cash flow, even on creditworthiness of a powerful buyer (reverse factoring). Thus the bank has the advantage in a relatively risk-free placement towards a client who could not obtain external finance otherwise. Of course, this form of finance also contributes to the increase in the bank's profitability ${ }^{5}$.

By applying various techniques of supply chain management, companies enhance liquidity (by reducing gaps between the physical flow of goods and flow of cash), which is a field where commercial banks, due to the heightened interest of their clients, may seek their own interest and benefits. Thus, companies conduct various forms of improving the supply chain efficiency, being familiar with the subject matter in the field, whereas banks may offer new solutions in the form of different products to finance the supply chain.

The concept of supply chain finance is related to the flow of goods and cash, and owing to its solutions it helps the clients to reduce their inventories, meet production deadlines more easily, and implement better management of their receivables and liabilities. This definitely enables smaller and more frequent procurements, as opposed to one or several big ones, which facilitates risk mitigation and enables better cash flow within the supply chain. This also accelerates the cash flow. Through a certain product for supply chain financing, the bank not only encourages the isolation of a cash flow for the purpose of its own exposure repayment, but also accelerates it and enhances it on a wider scale.

Given the current recession, productsrelated innovations and flexibility in the approach to the client's needs generate new attractive possibilities for finance, increasing the banks' chances for profit, and for the position in which they are client-oriented as they have never been before. There is an extremely close relationship which generates long-term ties between the client and the bank. On the other hand, the concerned products are, unlike classic credit arrangements, risk-free. To sum up, due to the sound structure of the transaction, banks locate the best product; establish long-term ties with the client, and start an extremely profitable and safe arrangement ${ }^{6}$

In order to optimize their working capital and accelerate the cash flow, clients apply different techniques of supply chain management. Rather frequently they use capital from operational business to invest it in various segments controlling and facilitating the supply chain efficiency (procurement logistics, sales, new machinery and equipment, etc.), thereby jeopardizing current liquidity. If the bank offers them its own solution in the form of an adequate financial instrument, the clients may maintain liquidity and improve the supply chain efficiency.

\section{Variations of Supply Chain Finance Products}

- Pre-shipment finance - Financing based on inventories with warehouse certificates

\footnotetext{
5 Carswell, Kitt, Product Manager and Executive Consultant within CGI's Trade Services Group, “Supply Chain Finance: A new way for trade banks to strengthen customer relationships", 2007, p. 10

6 Bryant,Charles and Camerinelli, Enrico, EBA (Euro Banking Association), „Supply chain finance“, 2012, p. 18
} 
trade finance) - finansiranje klijenata iz ino-izvora (crossborder finance) na bazi strukture transakcije koja rezultuje izolacijom novčanog toka i usmeravanjem istog ka otplati odnosne izloženosti

\section{Finansiranje faze poslovanja pre isporuke}

\section{Finansiranje izvoznika na bazi narudžbenice uvoznika}

Kod finansiranja izvoznika na bazi narudžbenice kupca (PO based finance), banka kupca (uvoznika) inicira proces finansiranja. Konkretno, banka kupca (uvoznika) dobija narudžbenicu (purchase order (PO) ) od kupca (uvoznika) koju je on poslao izvozniku, uz molbu da pošalje upit za finansiranje na bazi narudžbenice nekoj od izabranih banaka koje prate poslovanje izvoznika. Potom, banka kupca (uvoznika) šalje upite, a banka koja je pristala na transakciju dobija narudžbenicu od izvoznika koju je on dobio od uvoznika lociranog u drugoj zemlji. U Evropi, banke izvoznika i banke uvoznika narudžbenice dobijene od različitih strana upoređuju u posebnoj aplikaciji u mreži „swift-a" - TSU (Trade service unit) i ukoliko se podudaraju predlog finansiranja od strane banke izvoznika može biti poslat izvozniku (eliminisan rizik falsifikovanja narudžbenice). Banke pored usaglašavanja narudžbenica, sarađuju i na polju razmene informacija o kreditnim bonitetima partnera, učestalosti isporuka, dužini saradnje, tržišnim pozicijama, efikasnosti plaćanja i drugim aspektima, a usled negativnog poslovnog okruženja i težnje ka zaštiti sopstvenih interesa. Banka uvoznika je spremna da obezbedi neophodne podatke o svom klijentu, jer je inicijator posla i želi da svog klijenta podrži u domenu jačanja odnosa u lancu snabdevanja. Razlika u odnosu na kratkoročni kredit za obrtni kapital je u tome da se mnogo više pažnje posvećuje komunikaciji između banaka radi utvrđivanja svih činjenica vezanih za poslovne partnere u lancu snabdevanja.
Slika 1: Finansiranje izvoznika na bazi narudžbenice uvoznika

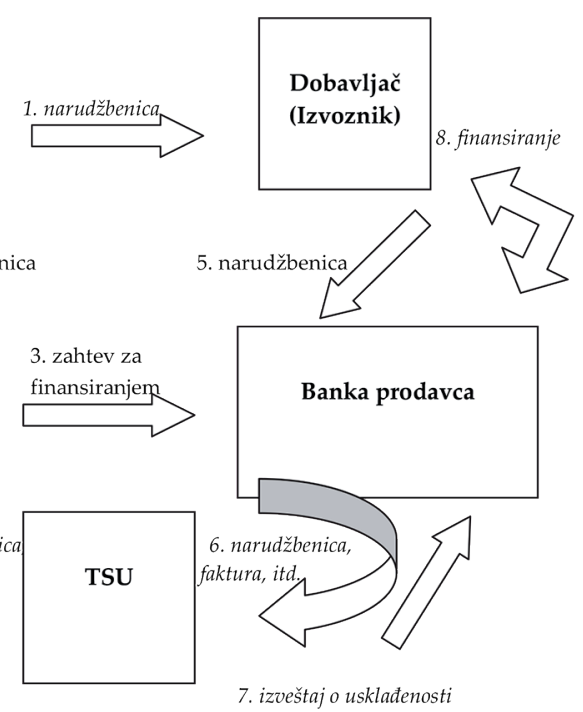

Korist za izvoznika je finansiranje aktivnosti koja prethodi isporuci (nabavka dodatne sirovine ili gotovog proizvoda kako bi se kompletirala pošiljka robe, isplatile plate radnicima, podmirili troškovi pakovanja, itd.). Ipak, banka ima nekoliko ograničenja. Kao prvo postoji relativno visok rizik finansiranja jer se isto bazira isključivo na narudžbenici. Preporučljiv je način finansiranja ako postoji duga istorija poslovanja između partnera i visoka međuzavisnost poslova učesnika $u$ transakciji (zavisnost koja isključuje svaki izazov da se izbegne ili isporuka ili plaćanje) ${ }^{8}$. Banka izvoznika mora dobro da poznaje aktivnosti poslovnih partnera, stepen njihove međuzavisnosti, ali i dokumentaciju koja se vezuje za posao (ugovor, faktura, itd.), a u tome ima pomoć banke kupca.

Finansiranje izvoznika na bazi narudžbenice uvoznika praćeno garancijom odnosno bankarskom platnom obligacijom kao instrumentom obezbeđenja

Kod ovog tipa finansiranja banka kupca izdaje obavezu da plati banci prodavca ((plativa garancija ili trenutno sve popularniji instrument bankarska platna obligacija ili BPO (Bank payment obligation)), a kada prodavac otpremi robu i dostavi sva dokumenta koja se podudaraju sa nalogom za kupovinu i 
as collateral, based on purchase order or on assumption of liability for payment by another institution based on the purchase order.

- Shipment finance - Discounting of export letters of credit.

- Post-shipment finance - Financing based on receivables towards the buyers - purchase of receivables, discount of draft bills, factoring and reverse factoring?.

Structured trade finance - Financing the clients from foreign sources (cross-border finance) based on the transaction structure resulting in the isolation of the cash flow and its direction towards the repayment of the concerned exposure.

\section{Pre-shipment finance}

\section{Exporter financing based on importer's purchase order}

In the process of financing the exporter based on the importer's purchase order (PObased finance), the buyer's (i.e. importer's) bank initiates the finance. More precisely, the buyer's (i.e. importer's) bank receives from the buyer (importer) the purchase order (PO) that he sent to the exporter, asking him to file a PO-based finance request with one of the selected banks monitoring the exporter's business. After that, the buyer's (i.e. importer's) bank sends the requests, and the bank having agreed to the transaction receives the purchase order from the exporter, previously sent to him by the importer located in another country. In Europe, exporters' banks and importers' banks compare purchase orders received from different parties in a specially designed application within the SWIFT network, the so-called Trade Service Unit (TSU), and, if they match, the financing proposal by the exporter's bank can be sent to the exporter (this eliminates the risk of counterfeit purchase orders). In addition to comparing purchase orders, banks also cooperate in the field of exchanging information about the creditworthiness of counterparties, frequency of deliveries, duration of the cooperation, market positions, payment efficiency and other aspects, as a result of negative business environment and tendency to protect one's own interests. The importer's bank is ready to provide necessary data about its client, because it has initiated the operation and wishes to support its client in terms of strengthening the relations within the supply chain. The difference compared to a short-term working capital loan lies in the fact that much more attention is devoted to interbank communication with a view to determining all facts related to business partners in the supply chain.

Figure 1: Exporter financing based on importer's purchase order

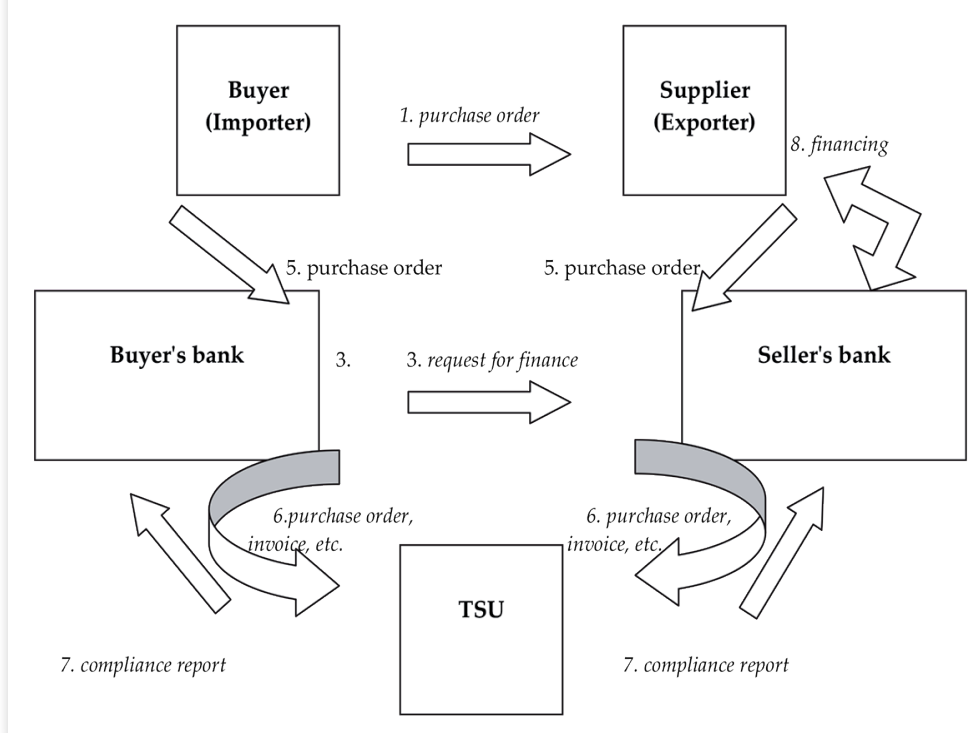

The benefit for the exporter is the financing of activities preceding the delivery (procurement of additional raw materials or finished products in order to complete the shipment of goods, disburse workers' wages, settle the packaging costs, etc.). Nevertheless, the bank has to respect several limitations. First of all, there is a relatively high risk of financing, because it is exclusively based on the purchase order. This form of finance is recommended when there

7 Carswell, Kitt, Product Manager and Executive Consultant within CGI's Trade Services Group, “Supply Chain Finance: A new way for trade banks to strengthen customer relationships", 2007, p. 7 
ostalim navedenim uslovima. Na bazi BPO-a banka prodavca dostavlja ponudu za finansiranje faze poslovanja koja prethodi isporuci. BPO se može smatrati i elektronskim akreditivom. To je novi finansijski instrument na relaciji banka-banka. Predmetni način finansiranja omogućava banci prodavca ali i prodavcu da se bazira na riziku banke koja je izdala svoju neopozivu nameru da plati, gde rizik izvršenja (performance risk) prodavca sa stanovišta banke prodavca ipak nije eliminisan (obligacija se može aktivirati samo ako je isporučena adekvatna roba, odnosno ukoliko je dokumentacija saglasna). BPO je inovacija u metodi sigurnosti naplate i plaćanja. Radi se o neopozivoj obavezi banke da plati određeni iznos banci primaocu u skladu sa prihvaćenom osnovom konkretne transakcije, a nakon usaglašavanja dokumenata u TSU. TSU je aplikacija smeštena u mreži „swift-a“ i dostupna je onim institucijama koje su korisnici ovog sistema. BPO je dakle neopoziva obaveza banke izdavaoca da plati po uspešnom, automatizovanom uparivanju odabranih podataka (primer narudžbenica vs. faktura, otpremna dokumenta itd.). Međunarodna trgovinska komora je u maju 2013 kreirala i izbacila jednoobrazna pravila za BPO (ICC URBPO) koja su donela sigurnost svim učesnicima i na kojima svi učesnici baziraju svoje ponašanje i realizuju ciljeve. Razlika u odnosu na akreditiv je $\mathrm{u}$ automatizovanom uparivanju podataka bez fizičkog dostavljanja dokumentacije, kao i u uparivanju podataka i preuzimanju obaveza na relaciji „banka banka“, a ne na relaciji "banka - preduzeće“ (akreditiv). ${ }^{9}$ oznika na bazi narudžbenice uvoznika praćeno garancijom banke (BPO) kao instrumentom obezbeđenja
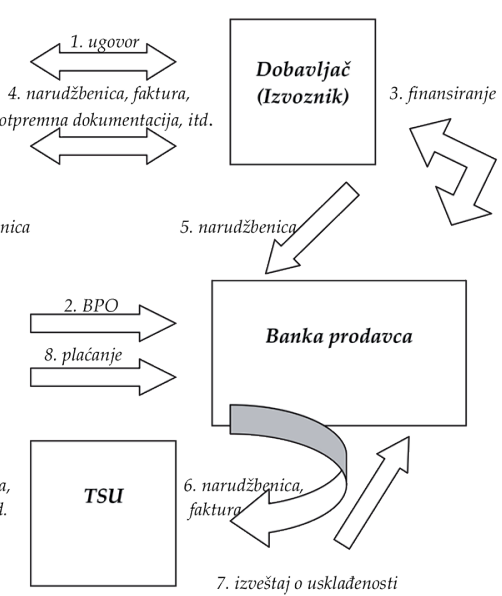

Banka kupca pored zarade na BPO-u ima interes da podrži svog klijenta $u$ domenu jačanja poverenja $\mathrm{u}$ odnosu sa prodavcem (obezbeđenje kontinuiteta isporuka i osnova za pregovaranje o boljim uslovima sa strateški važnim dobavljačima ili pak ulazak u poslovni aranžman sa novim dobavljačem). S druge strane banka prodavca pored zarade na kreditu želi da uz manji rizik podrži svog klijenta u obezbeđenju kontinuiteta poslovnog ciklusa. Prednost ovog vida finansiranja jeste u boljem poznavanju potreba učesnika u lancu snabdevanja (posmatrano u odnosu na klasičnu garanciju za odloženo plaćanje), jer povezanost firmi omogućava poznavanje trenutnih „gapova" u novčanom toku prodavca koji se mogu prevazići finansiranjem zasnovanom na riziku banke izdavaoca (po pitanju plaćanja), te i prodavac može da ima bolje uslove finansiranja zasnovane na riziku banke izdavaoca BPO-a.

\section{Finansiranje na bazi zaliha proizvoda}

U pitanju je poseban oblik finansiranja trgovine $u$ okviru koga se vrši finansiranje prodavca na bazi zaloge nad robom koja se skladišti u skladištu kvalificirane treće strane (ovlašćeno - sertifikovano skladište) uz prenos (indosiranje) skladišnica (potvrda o uskladištenju) u korist banke (predstavlja dokaz vlasništva nad robom) i uz kontrolu zaliha od strane za banku prihvatljive nadzorne agencije

9 International finance corporation, World Bank group, "Bank payment obligation: Financial instruments to manage risk in open account trade”, 2013, p. 3; International Chamber of Commerce, „Bank payment obligation (managing risk, finance and processing efficiency for open account trade in a multi-bank environment)", 2012, p. 3; City Trade University, "SWIFT Net Trade Services helping banks meet the supply chain challenge", 2008, p. 11 
is a long history of doing business between the partners, and high interdependence of operations conducted by transaction participants (i.e. dependence excluding any challenges to avoid either delivery or payment) $)^{8}$. The exporter's bank must be well acquainted with the activities of business partners, the level of their interdependence, but also the documentation related to the operation (contract, invoice, etc.), in which respect it gets the assistance of the importer's bank.

\section{Exporter financing based on importer's} purchase order, secured by a bank guarantee, i.e. a bank payment obligation (BPO) as collateral

In this type of finance, the buyer's bank issues the obligation to pay to the seller's bank (payment guarantee or the increasingly popular instrument - bank payment obligation (BPO)), concrete transaction, following the compliance of documents in the TSU. TSU is an application located in the SWIFT network, available to the institutions using this system. BPO is, thus, an irrevocable obligation of the issuing bank to pay upon a successful, automated mapping of selected data (for instance, purchase order versus invoice, shipping documents, etc.). In May 2013 the International Chamber of Commerce created and published the Uniform Rules for BPO (ICC URBPO), which brought security to all participants, and established the basis in terms of how the participants should behave and implement their goals. The difference compared to a letter of credit lies in the automated mapping of data without the physical submission of documents, and in the mapping of data and assumption of obligations on a bank-to-bank basis, instead of on a bank-to-business basis (as in the letter of credit). after the seller ships the goods and submits all documents matching the purchase order and other stipulated conditions. Based on the BPO, the seller's bank submits the offer for financing the business stage preceding delivery. $\mathrm{BPO}$ can also be considered an electronic letter of credit. It is a new financial instrument on a bank-to-bank basis. The concerned manner of financing enables the seller's bank, but also the seller, to focus on the risk of the bank having issued its irrevocable obligation to pay, with the performance risk of the seller, from the perspective of the seller's bank, nevertheless, not being eliminated (the obligation can be activated only if the delivered goods are adequate, and the relevant documentation compliant). BPO is innovative as a method of safe collection and payment. It represents an irrevocable obligation of the bank to pay a certain amount to the recipient bank, in line with the accepted basis of the

Figure 2: Exporter financing based on importer's purchase order, secured by a bank guarantee (BPO) as collateral

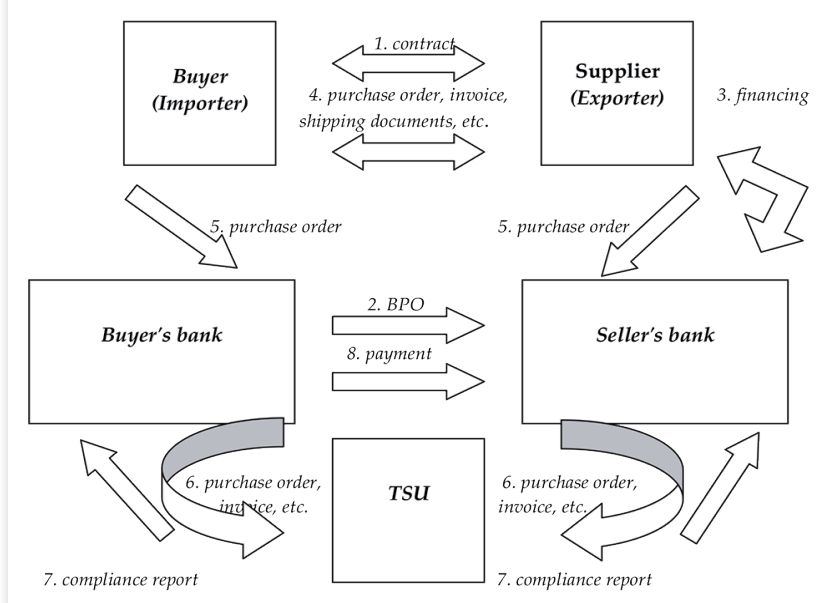

The buyer's bank, in addition to its earnings from the BPO, has the interest to support its client in terms of building the confidence in his relationship with the seller (ensuring the continuity of deliveries and the basis for negotiating better conditions with strategically important suppliers, or closing a business arrangement with a new supplier). On the other hand, the seller's bank, in addition to

8 Bryant, Charles and Camerinelli, Enrico, EBA (Euro Banking Association), „Supply chain finance“, 2012, p. 59

9 International finance corporation, World Bank group, "Bank payment obligation: Financial instruments to manage risk in open account trade”, 2013, p. 3; International Chamber of Commerce, „Bank payment obligation (managing risk, finance and processing efficiency for open account trade in a multi-bank environment)", 2012, p. 3; City Trade University, "SWIFT Net Trade Services helping banks meet the supply chain challenge", 2008, p. 11 
i prijem mesečnih ili češćih izveštaja o stanju i količini zaliha. Kratkoročni kredit na bazi skladišnice predstavlja kreditni aranžman po kome poverilac preuzima potpunu kontrolu nad kolateralnim obezbeđenjem duga ${ }^{10}$. Ovlašćeno skladište je odgovorno za robu dok je ona u njemu, što znači da je instrument obezbeđenja zaštićen od eventualnih nepredviđenih, nesrećnih okolnosti (požar, poplava, krađa itd.). Finansiranje prodavca na bazi zaliha predstavlja finansiranje na bazi odnosa vrednosti zaliha i plasiranog kredita. Predmetna transakcija podrazumeva obavezu određivanja koeficijenta koji mora da bude ispunjen kada je u pitanju odnos nominalne, tržišne vrednost zaliha i kredita banke. To znači da kada se otplati deo kredita uspostavljeni koeficijent pruža mogućnost definisanja koliko tačno zaliha može biti oslobođeno. Ukoliko prodavac otplati deo kredita skladišnica se mora osloboditi od strane banke u korist prodavca ili u korist kupca koji kupovinom robe, tj. otplatom kredita $u$ ime prodavca stiče vlasništvo nad robom. Dakle, roba prati kretanje novca, a samim tim i titular prava na robi se menja. Veći stepen rizika utrživosti zaliha, ali i promene cena zaliha (berzanska roba) uslovljava i neophodnost uspostavljanja većeg koeficijenta vrednosti založenih zaliha $\mathrm{u}$ odnosu vrednost plasiranog kredita. Zalihe moraju biti utržive jer je to jedini izvor otplate u slučaju bankrotstva (default-a). Ipak, zalihe su najrizičniji kolateral iz domena obrtne imovine usled tržišnih turbulencija cene, ali i rizika realizacije. Putem finansiranja prodavca na bazi zaliha eliminisan je tzv. rizik proizvodnje. Roba je proizvedena i predstavlja kolateral uspostavljen u korist banke, što štiti kupca koji nabavku robe plaća avansnom uplatom na kreditnu partiju prodavca. Kvalitet robe se lako kontroliše (postoji mogućnost kontrole robe prostim uvidom $\mathrm{u}$ istu što od strane banke, što od strane kupca), a i transportni rizik se pomera sa prodavca na kupca robe (kupac kupovinom robe vrši transport iste od skladišta do svojih poslovnih kapaciteta).

Slika 3: Finansiranje na bazi zaliha proizvoda
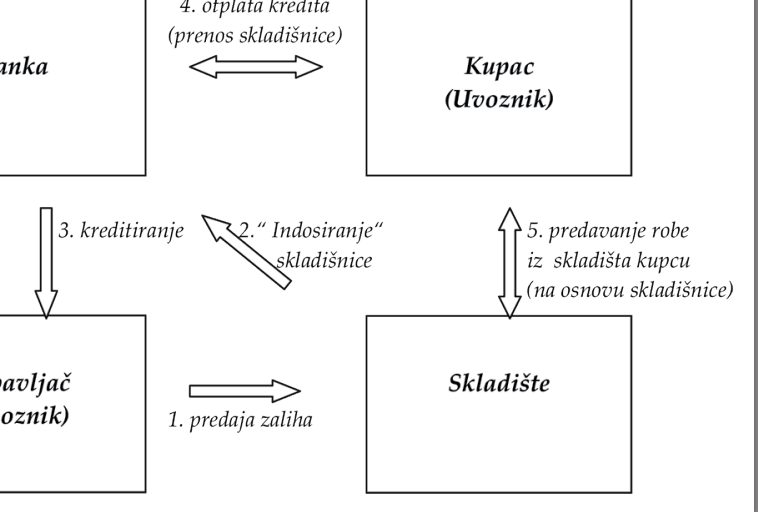

Finansiranje faze poslovanja tokom isporuke - diskontovanje izvoznih akreditiva

Diskontovanje izvoznog akreditiva predstavlja kratkoročni kredit za finansiranje perioda nakon prijema akreditiva, ali pre izvršenog plaćanja od strane kupca (uvoznika) ili kupčeve banke (akreditivna banka), na bazi primljenog akreditiva sa odloženim rokom plaćanja (prijem akreditiva preko banke koja odobrava proizvod), a sa prethodno usaglašenom prezentacijom dokumentacije i dobijenom "swift" porukom od strane akreditivne banke da će plaćanje biti izvršeno o dospeću plaćanja po akreditivu i to preko banke koja diskontuje akreditiv (poruka o prihvatanju (accept-u) otpremne dokumentacije od strane akreditivne banke = preuzimanje obaveze plaćanja). Naziva se proizvodom faze isporuke jer se finansiranje vrši od momenta isporuke robe i prihvatanja otpremne dokumentacije od strane akreditivne banke. Finansiranje se obavlja na kratak rok, u korist izvoznika, kojim on može da reši određene likvidnosne "gapove“ (pakovanje naredne porudžbine, plate itd.). Maksimalan rok transakcije je od trenutka

9 International finance corporation, World Bank group, “Bank payment obligation: Financial instruments to manage risk in open account trade”, 2013, p. 3; International Chamber of Commerce, „Bank payment obligation (managing risk, finance and processing efficiency for open account trade in a multi-bank environment) ", 2012, p. 3; City Trade University, "SWIFT Net Trade Services helping banks meet the supply chain challenge", 2008, p. 11

10 Krasulja Dragan, Ivanišević Milorad: „Poslovne Finansije“, Ekonomski fakultet u Beogradu, 2001, str. 437 
its earnings from the loan, wishes to support its client, at the lower risk, in providing the business cycle's continuity. The advantage of this form of finance is reflected in the higher awareness of the needs of the supply chain participants (compared to the classic deferred payment guarantee), because the connectedness of firms enables them to be familiar with the current gaps in the seller's cash flow that can be overcome through financing based on the issuing bank's risk (in respect of payment), and the seller can get better financing conditions based on the risk of the $\mathrm{BPO}$ issuing bank.

\section{Inventory financing}

This is a special form of trade finance within which the seller gets financed based on a pledge over goods stored at the warehouse of a qualified third party (certified warehouse), with the transfer (endorsement) of warehouse certificates (storage confirmations) to the benefit of the bank (as a proof of ownership over the concerned goods), and the relevant control of inventories by the supervisory agency acceptable to the bank, and receipt of monthly or more frequent reports on the condition and amount of goods. Short-term loan based on a warehouse certificate is a credit arrangement awarding the creditor full control over the collateral-based protection of the debt ${ }^{10}$. The certified warehouse is responsible for the goods during the time it is stored there, which means that the collateral is protected from potential unforeseen, unfortunate circumstances (fire, flood, theft, etc.). Inventorybased financing of the seller is financing based on the ratio of the value of inventories and the granted loan. The concerned transaction implies the obligation to determine the ratio that has to be reached when it comes to nominal market value of inventories and the bank's loan. This means that, once a segment of the loan gets repaid, the established ratio provides the possibility to define how many inventories exactly can be released. If the seller repays a portion of the loan, the warehouse certificate has to be released by the bank to the benefit of the seller, or to the benefit of the buyer who has acquired ownership of the goods by purchasing it, or by repaying the loan on behalf of the seller. In other words, the goods follow the flows of cash, which, in turn, implies that the bearer of rights over the concerned goods may change. The higher level of risk concerning the marketability of inventories, but also the volatility of prices of these inventories (stock exchange commodities), conditions the necessity of establishing a higher ratio of the stored inventories' value and the value of the granted loan. Inventories must be marketable, given that they serve as the only source of repayment in case of default. Nevertheless, inventories are the most risky collateral in the category of working assets due to market volatility of prices, and performance risk. By financing the seller based on inventories, one eliminates the so-called production risk. The goods have been produced, and serve as collateral established to the benefit of the bank, protecting the buyer who is paying for the procurement of goods by effecting an advance payment into the seller's credit line. The quality of goods is easily controlled (there is a possibility for both the bank and the buyer to control the goods by simple insight), and the transportation risk is transferred from the seller to the buyer of goods (by purchasing the goods, the buyer gets in charge of transportingthem from the warehouse to his business premises).

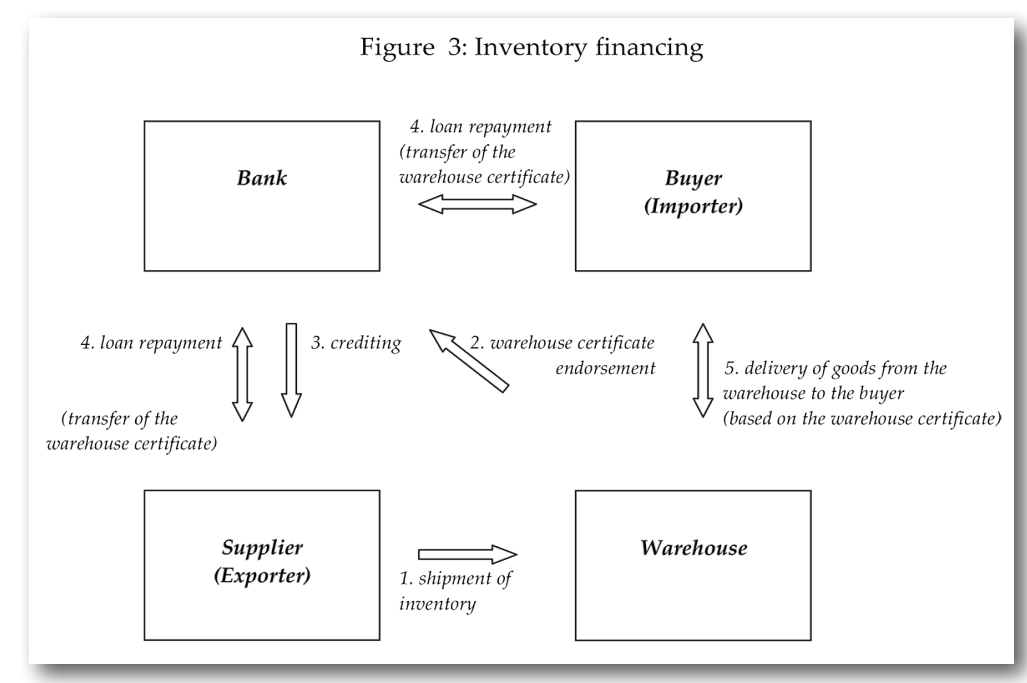

10 Krasulja Dragan, Ivanišević Milorad: „Poslovne Finansije“, Ekonomski fakultet u Beogradu, 2001, str. 437 
prijema „swift“ poruke o prihvatanju otpremne dokumentacije pa sve do konačnog dospeća plaćanja po akreditivu. Maksimalan iznos koji se odobrava je do $100 \%$ vrednosti potraživanja pokrivenog akreditivom. Troškovi transakcije za korisnika finansiranja su naknada za obradu zahteva i kamata koja se obračunava na rok i iznos avansnog plaćanja. Naplata se vrši jednokratno o dospeću od priliva po osnovu izvoznog posla pokrivenog akreditivom

Prednosti transakcije za izvoznika: Finansiranje bez regresa na klijentu (rizik akreditivne banke) - priliv novca bez preuzimanja obaveze; Poboljšanje likvidnosti (ubrzanje novčanog toka kroz avansnu uplatu); Brža potraživanja u novac; Povećanje profita (plaćanje dobavljaču pre roka uz prijem avansnog rabata koji je veći od troškova diskontovanja); Bolja struktura pasive (ako se izvrši plaćanje dobavljaču ili drugom kreditoru - bolji indikator kapitala).

Prednosti transakcije za banku: Mali nivo rizika usled baziranja istog na akreditivnoj banci; Eliminisan rizik izvršenja - prihvaćena otpremna dokumentacija = dokaz isporuke; Eliminisanje rizika zemlje kupca; Jednostavna, brza i visokoprofitabilna transakcija.

\section{Finansiranje faze poslovanja nakon isporuke}

U pitanju su proizvodi za finansiranje učesnika kada se izvoz završio i kada postoje otpremna dokumenta koja dokazuju postojanje potraživanja. U tim i sličnim situacijama prodavac je proknjižio potraživanje, a kupac obavezu u finansijskim izveštajima. Predmetna faza podrazumeva sledeće proizvode: faktoring, obrnuti faktoring, kredit pokriven polisom osiguranja za rizik nenaplativosti potraživanja (u slučaju stečaja krajnjeg kupca), izdata od strane agencije za kreditiranje izvoza (export credit agency), potom kredit u korist kupca (buyer's credit), forfeting i razne varijacije pomenutih proizvoda.

Kredit pokriven polisom osiguranja od strane agencije za kreditiranje izvoza (u RS Agencija za osiguranje i finansiranje izvoza Republike Srbije (AOFI)), podrazumeva kreditiranje na bazi vinkulacije polise $u$ korist banke određujući banku kao korisnika polise u slučaju realizacije osiguranog slučaja (bankrotstva krajnjeg kupca). Predmetni proizvod je veoma rasprostranjen način finansiranja izvoznika u različitim zemljama sveta (agencije za kreditiranje izvoza imaju veće kratkoročne pokazatelje gubitaka jer pokrivaju pun spektar rizika - ukupna suma plaćenih realizovanih osiguranih slučajeva raste pod osiguranjem predmetnih agencija sa 2,5 milijardi USD u 2011. godini na 2,6 milijardi USD u 2012. godini $^{11}$ ), dok je u RS prilično zapostavljen, a usled nejasno definisane uloge domaće agencije.

Kredit $\mathrm{u}$ korist kupca predstavlja kredit banke izvoznika odobren uvozniku uz garanciju od strane banke uvoznika ili garanciju države uvoznika ili uz osiguranje agencije za kreditiranje izvoza zemlje izvoznika, a kako bi tim sredstvima platio dug prema izvozniku za izvršenu isporuku robe ili usluge. Radi se o rasprostranjenom načinu kreditiranja poslovnih subjekata različitih zemalja sveta, a RS je interesantna za one izvoznike koji izvoze proizvode visoke vrednosti uvoznicima $u$ vlasništvu države (javna preduzeća). Kako bi podržale sopstvene izvoznike i smanjile rizik naplate banke odobravaju kredite uvoznicima u drugim zemljama, gde je lokalna banka u obavezi da izvrši kontrolu prijema novca na račun uvoznika i usmeravanja istog direktno na račun izvoznika.

Banke često $\mathrm{u}$ domenu finansiranja faze poslovanja nakon isporuke sarađuju i na taj način što banka izvoznika plaća za isporučenu robu svome klijentu avansno, ali posle dobijene „swift" poruke od strane banke uvoznika da će ona u ime klijenta platiti dug o roku dospeća. Naravno, pre dostavljanja ",swift" poruke banka uvoznika bi imala odluku o finansiranju svog klijenta sa rokom dužim od recimo 30 dana od dana inicijalnog dospeća (ugovorenog između izvoznika i uvoznika). Po dospeću, sredstva bi bila plasirana tzv. „kontra-nalogom“ (direktno na račun banke izvoznika), a klijent (uvoznik) bi namirio dug uz odloženo plaćanje od 30 dana duže od inicijalnog roka. Na ovaj način izvoznik bi imao sigurnu i avansnu uplatu (brži ciklus gotovine) uz cenu aranžmana baziranu 


\section{Shipment finance - Discounting of export letters of credit}

Discounting of an export $\mathrm{L} / \mathrm{C}$ is a short-term loan for financing the period following the reception of the $\mathrm{L} / \mathrm{C}$, but prior to the executed payment by the buyer (importer) or the buyer's bank (issuing bank), based on the received letter of credit with a deferred payment deadline (L/C is received via the bank approving the product) and a previously complying presentation of documents and a received SWIFT message from the issuing bank, stating that the payment will be effected upon the L/C maturity, via the bank discounting the concerned letter of credit (message about shipping documents being accepted by the issuing bank = assumption of payment obligation). It belongs to the category of shipment finance because the financing is conducted from the moment the goods are shipped and shipping documents accepted by the issuing bank. The financing is shortterm, to the benefit of the exporter, enabling him to settle certain liquidity gaps (packing the next order, wages, etc.). The maximum duration of the transaction ranges from the moment of receiving a SWIFT message on the shipping documents being accepted, until the final maturity of the $\mathrm{L} / \mathrm{C}$ payment. The maximum allowable amount is up to $100 \%$ of the value of receivables covered by the $\mathrm{L} / \mathrm{C}$. Transaction costs for the beneficiary include the fee for application processing, and the interest calculated on the duration and amount of the advanced payment. The collection is one-off, upon maturity of inflows in respect of the export operation covered by the $\mathrm{L} / \mathrm{C}$.

Advantages of the transaction for the exporter: financing without recourse against the client (the issuing bank's risk) - inflow of cash without assuming the responsibility; improved liquidity (accelerated cash flow owing to advance payment); quicker conversion of receivables to cash; higher profit (payment to the supplier before deadline with an advance discount higher than discounting costs); better structure of liabilities (if the payment is effected to the supplier or other creditor - better capital indicator).

Advantages of the transaction for the bank: low level of risk due to its being based on the issuing bank; eliminated performance risk - accepted and compliant shipping documents $=$ proof of shipment; elimination of the buyer's country risk; simple, quick and highly profitable transaction.

\section{Post-shipment finance}

These are the products financing participants once the export is complete and once there are shipping documents to prove the existence of receivables. In these and similar situations, the seller has booked the receivable, and the buyer the correspondent liability in the financial statements. The concerned stage includes the following products: factoring, reverse factoring, credit backed by an insurance premium against the risk of non-performance (in case of the ultimate beneficiary's default), issued by an export credit agency; then the buyer's credit, forfeiting and different variations of the listed products.

Credit backed by an insurance premium issued by an export credit agency (in the Republic of Serbia - Serbian Export Credit and Insurance Agency) implies crediting based on the premium assignation to the benefit of the bank, specifying the bank as the premium beneficiary in the event of the insured case (ultimate beneficiary's default). The concerned product is a very widespread method of export finance in various countries all over the world (export credit agencies have higher short-term loss indicators, because they cover a full range of risks - the total sum of paid realized insured cases under the insurance of the concerned agencies increased from 2.5 billion USD in 2011 to 2.6 billion USD in $2012^{11}$ ), whereas in the Republic of Serbia this product is rather neglected, due to the unclearly defined role of the domestic agency.

The buyer's credit is a credit granted by the exporter's bank to the importer, with a guarantee of the importer's bank or a guarantee of the importer's country, or with the insurance by the export credit agency from the exporter's country, so that these funds could be used to repay the debt towards the exporter for the completed delivery of goods or his other services. This is

11 ICC (The World Business Organization), “2013 Rethinking trade \& finance”, 2013, p. 52 
na rejtingu banke uvoznika (rejting banke je često bolji od rejtinga klijenata), a uvoznik bi imao produžen rok plaćanja (brži ciklus gotovine).

Faktoring, predstavlja finansijski posao u kojem banka (faktor) vrši otkup kratkoročnih potraživanja za prodatu robu ili izvršenu uslugu, pre dospeća za naplatu. Banka otkupljuje nastala, nedospela i nesporna potraživanja od klijenata na osnovu dokumenata kojima se dokazuje postojanje odnosnog potraživanja.

\section{Obrnuti faktoring}

Obrnuti faktoring je finansijski posao u kojem banka (faktor) finansira ispunjenje obaveza koje klijent (kupac) ima prema dobavljaču ili dobavljačima uz prenos potraživanja dobavljača na banku i obavezivanje kupca da plati banci. Banka finansira nastale, nedospele, nesporne obaveze klijenta (kupca) i preuzima odnosna potraživanja od odnosnih dobavljača klijenta (kupca), a na osnovu dokumenata kojima se dokazuje postojanje istih. Obrnuti faktoring po svojim svojstvima (prednostima za učesnike) ne odstupa značajnije od klasičnog faktoringa bez regresa, uz ključnu razliku što se ovim proizvodom finansira ispunjenje obaveza koje klijent ima prema dobavljaču, a ne otkup njegovih potraživanja.

Obrnuti faktoring je posebna vrsta faktoringa koji se ugovara između faktora i dužnika iz ugovora o prodaji robe ili pružanja usluga u zemlji i inostranstvu, na osnovu koga faktor, preuzimanjem faktura od dužnika, preuzima njegovu obavezu plaćanja prema poveriocima, a ima pravo naplate od dužnika u roku iz ugovora o prodaji robe ili pružanja usluga u zemlji i inostranstvu. $^{12}$
Slika 4: Mehanizam funkcionisanja obrnutog faktoringa

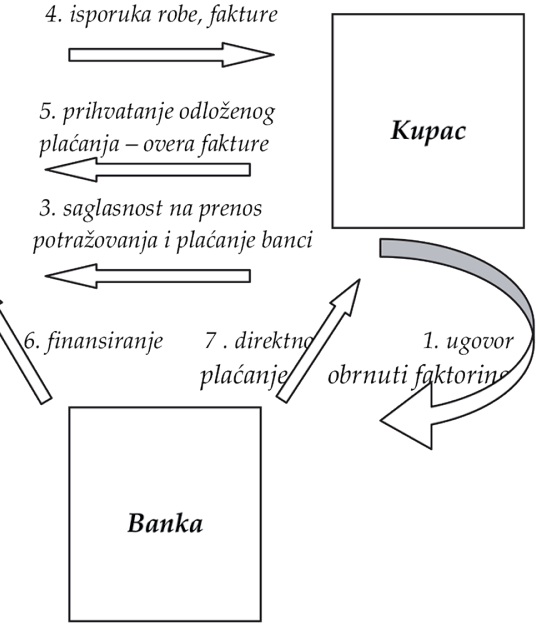

Obrnuti faktoring je redak primer tropartitnog aranžmana koji donosi benefite svim učesnicima transakcije: kupcu, dobavljaču i banci. ${ }^{13}$

Prednosti za kupca: 1. produženje roka plaćanja obaveza - brži novčani tok (Kada su kupac i dobavljač obavešteni o odobrenju transakcije obrnutog faktoringa, tada se pre realizacije i pre prenosa potraživanja sa dobavljača na faktora aneksira postojeća faktura ili ugovor u cilju produženja roka plaćanja od strane kupca odnosno naplate od strane dobavljača. Dobavljač pristaje na aneks jer je tako dogovoreno $\mathrm{u}$ fazi pregovora povodom aranžmana i jer zna da će brzo po potpisu aneksa dobiti novac i pre roka inicijalnog dospeća (dospeća pre aneksa). Takva "produžena potraživanja" se potom prenose na faktora, a kupac se obavezuje da će faktoru platiti u skladu sa novo-utvrđenim rokom plaćanja.); 2. proaktionije upravljanje obrtnim kapitalom; 3. manji troškovi procesuiranja plaćanja - plaćanje vrši faktor (banka); 4. mogućnost povećanja profita kroz avansni rabat za prevremeno plaćanje ka dobavljačima; 5. bolji odnosi sa dobavljačima uz stvaranje osnove za pregovore o boljim uslovima nabavke; 6. dobavljači su lojalniji a imidž preduzeća je bolji jer se posmatra kao firma koja brine o dobavljačima; 7. mogućnost korišćenja novca koji je akumuliran kako bi se izmirio dobavljač, za likvidnosno ili investiciono ulaganje; 8. klijent nema trošak jer isti pada na 
a widespread method of crediting commercial entities in various countries worldwide, and the Republic of Serbia is interesting for those exporters exporting large value products to the state-owned importers (public companies). In order to back their own exporters and mitigate the collection risk, banks extend credits to importers in other countries, where a local bank is obliged to control the reception of cash in the importer's account, and the redirection of that cash into the exporter's account.

When it comes to post-shipment finance, banks frequently cooperate in the following way as well: the exporter's bank effects an advance payment for the delivered goods to its client, but only after it receives the SWIFT message from the importer's bank, stating that it will, on behalf of the client, repay the debt upon maturity. Naturally, before sending that SWIFT message, the importer's bank would have to decide on financing its client with a deadline longer than, say, 30 days from the initial maturity date (agreed between the exporter and importer). Upon maturity, the funds would be placed via the socalled counter-order (directly into the exporter's bank account), and the client (importer) would settle the debt with deferred payment of 30 days longer than the initial deadline. Thus, the exporter has a safe and advance payment (quicker cash flow), with the arrangement price based on the importer's bank rating (the bank's rating is often higher than the client's rating), and the importer has an extended payment deadline (quicker cash flow).

Factoring is a financing operation in which the bank (factor) purchases short-term receivables in respect of the sold goods or provided service, before payment maturity. The bank purchases the originated, non-matured and undisputed receivables from the clients, based on the documents proving the existence of the concerned receivables.

\section{Reverse factoring}

Reverse factoring is a financing operation in which the bank (factor) finances the settlement of liabilities that the client (buyer) has towards the supplier(s), with the supplier's receivables being transferred to the bank, and the buyer being obliged to pay to the bank. The bank finances the originated, non-matured and undisputed liabilities of the client (buyer) and assumes the concerned receivables from the concerned suppliers of the client (buyer), based on the relevant documents proving their existence. In terms of its characteristics (advantages for stakeholders), reverse factoring does not considerably differ from classic factoring without recourse, the key difference being that this product finances the settlement of liabilities that the client has towards the supplier, instead of the purchase of his receivables.

Reverse factoring is a specific type of factoring contracted between a factor and a debtor under an agreement on the sale of goods or provision of services at home or abroad, whereby the factor assumes the debtor's invoices and thus also the debtor's payables owed to creditors, and acquires the right to collect the receivables due from the debtor by the deadline set in the agreement on the sale of goods or provision of services at home or abroad ${ }^{12}$.

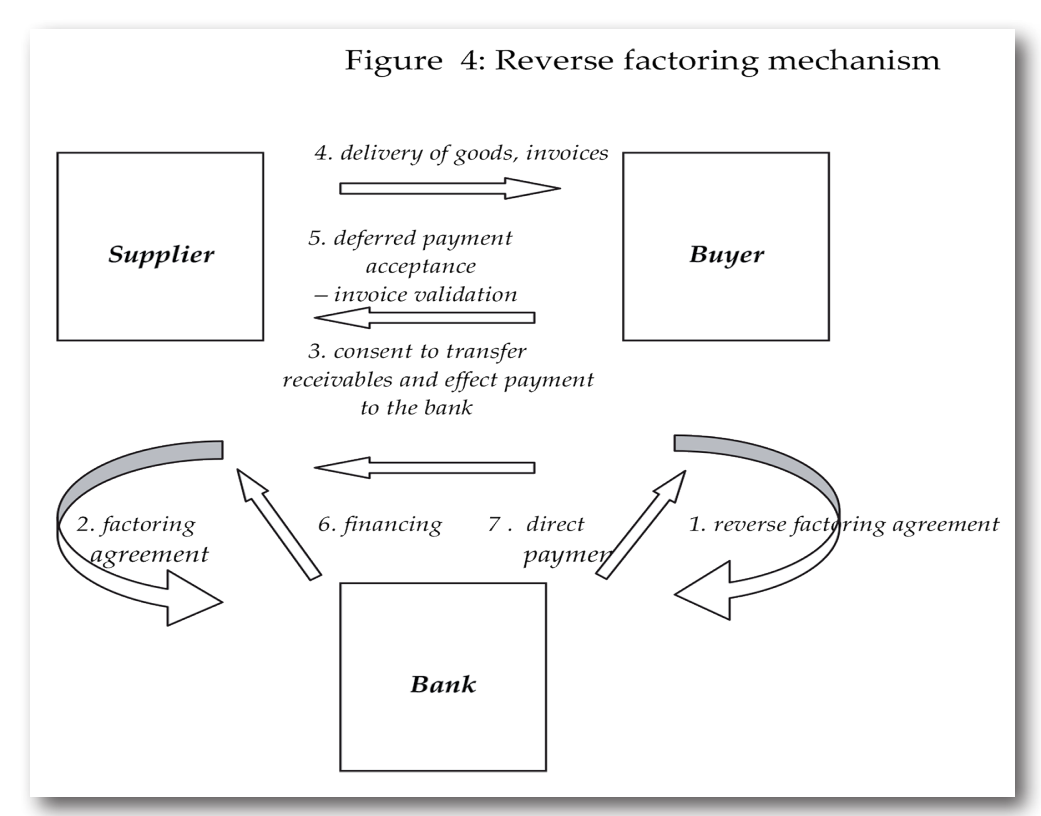


teret dobavljača (trošak naknade i kamate); 9. pojačava veze unutar lanca snabdevanja $i$ smanjuje mogućnost operationog rizika jer postoji dodatni kontrolor (banka). To se odnosi na proveravanje podataka na fakturama, uparivanje sa nalozima nabavke (narudžbenicama), uparivanje kartice otvorenih obaveza (kupac) i otvorenih potraživanja (prodavac) međusobno, ali i sa podacima iz faktura, narudžbenica itd.

Prednosti za dobavljača: 1. ubrzanje ciklusa gotovine, tj. brže pretvaranje potraživanja $\mathrm{u}$ gotovinu; 2. pristup dodatnom finansiranju koji možda ne bi bio moguć posmatrajući bilanse (pogotovo za mala preduzeća - najviše pogođena talasom nelikvidnosti); 3. manji troškovi finansiranja jer se trošak bazira na rejtingu jakog kupca; 4. eliminisanje rizika naplate potraživanja, ali i uštede po pitanju njihovog administriranja; 5. kada se linija za obrnuti faktoring jednom otvori i kada nastane pozitivna kreditna istorija postoji mogućnost zahtevanja diskontovanja u bilo kom trenutku života transakcije; 6. vanbilansni način finansiranja; 7. predvidljiviji novčani tok; 8. pojačava veze unutar lanca nabavke i smanjuje mogućnost operationog rizika jer postoji dodatni kontrolor (banka). To se odnosi na proveravanje podataka na fakturama, uparivanje sa nalozima nabavke (narudžbenicama), uparivanje kartice otvorenih obaveza (kupac) i otvorenih potraživanja (prodavac) međusobno, ali i sa podacima iz faktura, narudžbenica itd. ${ }^{14}$

Slika 5: Koristi obrnutog faktoringa za dobavljača

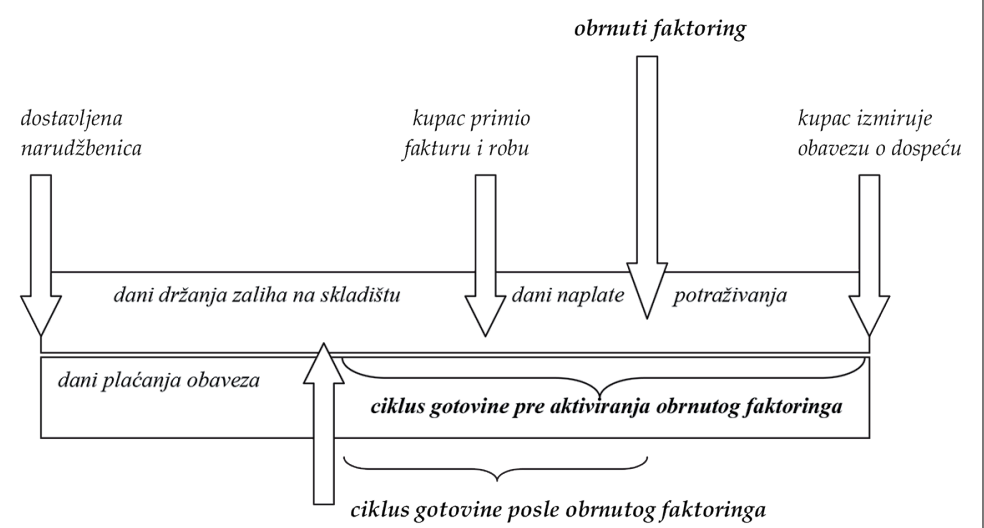

plaćanje obaveza
Prednosti za banku: 1. mogućnost rasta profitabilnosti usled manjeg rasta kapitalnih zahteva u odnosu na klasično kreditiranje; 2. dobijanje novih klijenata jer finansiranje većeg broja dobavljača jakog kupca "otvara vrata“ banci za saradnju sa njima; 3. omogućava jaču vezu i dugoročnu saradnju sa klijentom - kada se jednom implementira postaje struktura koja se ugrađuje u poslovni model učesnika koji postaju visoko zavisni od istog; 4. omogućava poslovni razvoj učesnika u lancu nabavke što rađa potrebu za drugim proizvodima banke; 5 . povećava potencijal drugih sektora $u$ banci - sektor sredstava (treasury), itd.

\section{Funkcionisanje faktoringa - avans, nominalna vrednost, garantni fond, ročnost}

Banka (faktor) na ime avansa, a po osnovu otkupa potraživanja, može isplatiti 70\%, $80 \%$, $90 \%$ ili viši procenat nominalne vrednosti prihvatljive fakture (overena od strane prodavca, ali i od strane kupca (delovodni pečat) ). Umesto overene fakture od strane kupca kao dokaz o nastanku potraživanja može se iskoristiti i otpremnica (overena od strane kupca), sa datumom prijema robe ili pismena potvrda kupca da je roba primljena. Na ovaj način se eliminiše tzv. rizik izvršenja, tj, rizik proizvodnje i otpreme adekvatne robe. Vrednost avansne isplate će pre isplate biti umanjena za naknadu za obradu zahteva, tj. faktoring provizije i za kamatu (obračunava se na iznos odobrenog, tj. ugovorenog avansa, prema periodu trajanja faktoring transakcije). Moguće je $\mathrm{u}$ određenim slučajevima ugovoriti plaćanje kamate i po naplati potraživanja. U slučaju naplate punog iznosa fakture od 100\%, banka (faktor) prenosi na račun klijenta preostalih 30\%, 20\% ili 10\%. Banka (faktor) prenosi ostatak iznosa, ali za isti nije odgovorna, jer je to deo prenetih potraživanja sa prodavca na faktora, a ne deo otkupljenih potraživanja (otkupljena potraživanja su

14 Carswell, Kitt, Product Manager and Executive Consultant within CGI's Trade Services Group, "Supply Chain Finance: A new way for trade banks to strengthen customer relationships", 2007, p. 9 
Reverse factoring is a rare example of tripartite arrangement yielding benefits for all transaction participants: the buyer, the supplier and the bank ${ }^{13}$.

Advantages for the buyer: 1. Extension of the liabilities payment deadline - quicker cash flow (When the buyer and the supplier get informed about the approved reverse factoring transaction, before the realization and before transferring the receivables from the supplier to the factor, the existing invoice or contract are annexed in order to extend the payment deadline for the buyer, i.e. the collection deadline for the supplier. The supplier agrees to the annex because it was arranged in the negotiating stage concerning the arrangement, and because he knows that soon after signing the annex, he will get his money, even before the expiry of the initial maturity (maturity before the annex). Such "extended receivables" are then transferred to the factor, and the buyer commits to effecting the payment to the factor in line with the newly-defined payment deadline.); 2. More proactive working capital management; 3. Lower payment processing costs - payment conducted by the factor (bank); 4. Possibility of increasing profit through advance discount based on early payment to suppliers; 5 . Generating better relations with the suppliers and the foundations for negotiations about better conditions for procurement; 6 . Suppliers are more loyal, and the company's image is improved, because it is viewed as a company caring about its suppliers; 7. Possibility of using the accumulated cash to honour the supplier, for either liquidity-related or regular investment; 8 . The client takes no costs because they are covered by the supplier (cost of fees and interest); 9. Ties within the supply chain are strengthened and the potential for operational risk gets reduced thanks to the additional controller (bank). This refers to examination of data on invoices, mapping with procurement orders (purchase orders), mutual mapping of balances of open payables (buyer) and open receivables (seller), but also their mapping with the data on invoices, purchase orders, etc.

Advantages for the supplier: 1. Quicker cash flow, i.e. quicker conversion of receivables into cash; 2 . Access to additional finance which perhaps would not have been possible based on the balances (especially in case of small enterprises - which were hit the most by the wave of illiquidity); 3. Lower costs of finance, given that the costs are based on a strong buyer's rating; 4. Eliminating the risk of receivables collection, and recording some cutbacks in respect of their administration; 5 . Once the reserve factoring line is opened, and the positive credit history is generated, there is a possibility of demanding a discount at any point during the lifetime of the transaction; 6. Off-balance sheet financing; 7. More predictable cash flow; 8 . Ties within the supply chain are strengthened and the potential for operational risk gets reduced thanks to the additional controller (bank). This refers to examination of data on invoices, mapping with procurement orders (purchase orders), mutual mapping of balances of open payables (buyer) and open receivables (seller), but also their mapping with the data on invoices, purchase orders, etc. ${ }^{14}$

Figure 5: Benefits of reverse factoring for the supplier

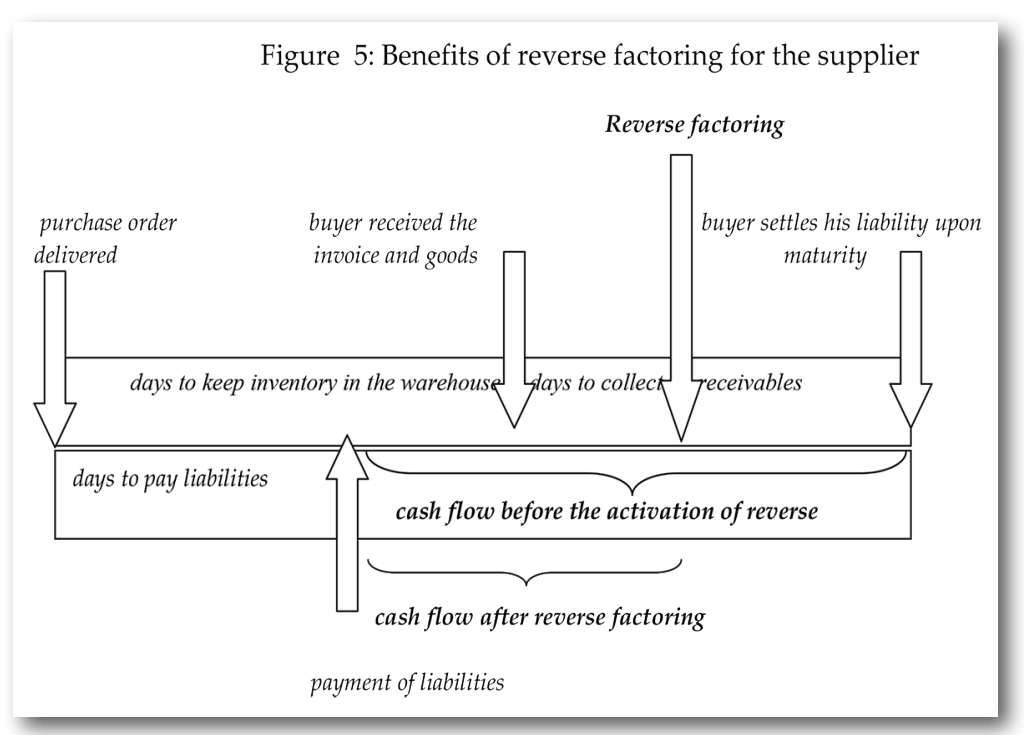

13 McKinsey on Payments, „Supply chain finance: from myth to reality“, October 2010, p. 24

14 Carswell, Kitt, Product Manager and Executive Consultant within CGI's Trade Services Group, "Supply Chain Finance: A new way for trade banks to strengthen customer relationships", 2007, p. 9 
jednaka iznosu isplaćenog avansa). Preostali iznos se može nazvati i garantni fond (faktoring rezerva). Garantni fond predstavlja učešće klijenta (prodavca) u riziku transakcije. Isplata $100 \%$ fakture umanjene za iznos naknade i kamate vrši se samo izuzetno, kada je rizik transakcije veoma nizak (faktoring sa pravom regresa; izuzetno snažna kompanija na strani prodavca, ali i kupca, po pitanju finansijskog i tržišnog položaja; dugoročna, uspešna istorija saradnje kupca i prodavca bez reklamacija, dodatni instrument obezbeđenja itd.). Visina garantnog fonda je direktno proporcionalna sa rizikom transakcije, tj. rizikom kupca, rizikom zemlje u slučaju izvoznog faktoringa, rizikom koncentracije na strani kupaca (faktoring sa jednim kupcem ili više kupaca), tipom faktoringa itd. Iznos avansa, odnosno garantnog fonda zavisi i od parametara koji karakterišu kvalitet istorijske saradnje prodavca i kupca, a prema dostupnim informacijama dobijenim od prodavca. Jedan od najvažnijih parametara se odnosi na eventualno postojanje sporova po pitanju kvaliteta isporuka i količina robe kojima su kupci uspevali da izdejstvuju plaćanje manjeg izosa u odnosu na nominalnu vrednost fakture (reklamacije). Takođe, važni su i istorijski podaci vezani za probijanje rokova plaćanja, rezultati analize ugovora između kupca i prodavca (postojanje eventualnih rabata, tj. diskonta za avansne uplate ili količinske nabavke), kao i eventualno istorijsko izmirivanje obaveza putem kompenzacija (kompenzaciono saldiranje potraživanja i obaveza smanjuje potencijal za faktoring). Neophodno je da svaki ugovor koji je predmet faktoringa, ali i faktura nedvosmisleno ukazuju na to da kompenzacija nije dozvoljena.

Prenos potraživanja sa prodavca na faktora se vrši potpisivanjem ugovora o faktoringu. Zakon o faktoringu je definisao da ugovor o faktoringu sadrži elemente ugovora o cesiji, te je isti dovoljan sa stanovišta prenosa potraživanja. Da bi prenos potraživanja imao pravno dejstvo neophodan je dokaz da je obaveštenje o prenosu potraživanja na faktora poslato kupcu. Ukoliko je obaveštenje poslato u skladu sa instrukcijom koju daje Zakon o faktoringu (mora da sadrži informacije o ugovoru o faktoringu, podatke o faktoringu kome je dužnik u obavezi da plati i instrukcije za plaćanje ${ }^{15}$ ), kupac ima zakonsku obavezu da plati na račun faktora umesto na račun prodavca. Kako bi se umanjio rizik transakcije većina faktora na domaćem tržištu zahteva verifikaciju obaveštenja od strane kupca, ali i dopis u kome kupac potvrđuje da je primio odnosnu robu odnosno uslugu i da će o roku dospeća platiti faktoru prema dostavljenoj instrukciji u obaveštenju. Fakture koje su predment otkupa putem faktoring transakcije, moraju da budu prihvatljive za faktora. Fakture moraju biti u formi sa delovodnim pečatom dužnika (kupca) ili bez uz drugačiji dokaz da je roba primljena. Minimalni, kvalitativni zahtevi su: naznačen rok plaćanja; naznačena vrsta i količina proizvoda; fakture koje su predmet otkupa ne smeju da sadrže klauzule o zabrani prenosa potraživanja; moraju precizno izraziti iznos svih eventualnih rabata u korist dužnika (avansni rabati, količinski rabati...); na fakturama ili drugačije mora biti naznačeno da kompenzacija nije dozvoljena.

\section{Forfeting}

Forfeting je otkup dugoročnog, nespornog, nedospelog i prenosivog potraživanja. Forfeting se zasniva na otkupu bez prava regresa na prodavcu. Učesnici u poslu forfetinga: domaći izvoznik (proizvođač - prodavac), inostrani uvoznik, banka (forfeter). ${ }^{16}$ Ugovor o forfetingu nije regulisan u uporednom pravu, kao što je to slučaj sa drugim ugovorima $u$ domenu robnog prometa - predstavlja tvorevinu bankarske i poslovne prakse. Poslovi kod kojih se javlja mogućnost forfetinga su: krupne, pojedinačne isporuke opreme, izgradnja objekata po sistemu ključ u ruke, izvođenje investicionih radova sa odloženim rokom plaćanja od jedne do nekoliko godina.

\section{Strukturno finansiranje trgovine}

Strukturno finansiranje trgovine (structured trade finance) je vrsta finansiranja iz inoizvora (cross-border) usmerenog ka tržištima u razvoju sa fokusom na tome da se transakcija sama likvidira odnosno otplati kretanjem 
Advantages for the bank: 1. Potential for increased profitability due to a smaller growth of capital requirements compared to classic crediting; 2. Attracting new clients because the financing of more suppliers of a strong buyer "opens the door" for the bank to establish cooperation with them; 3. Enabling stronger relations and long-term cooperation with the client - once it is implemented, it becomes a structure embedded in the business model of participants who grow highly dependent on it; 4. Enabling business development of supply chain participants, which in turn generates the necessity for other bank products; 5 . Increasing the potential of other sectors in a bank - treasury, etc.

\section{How factoring works - advance payment, nominal value, guarantee fund, maturity}

The bank (i.e. factor), in respect of the advance, based on the purchase of receivables, may disburse $70 \%, 80 \%, 90 \%$ or more, of the nominal value of the acceptable invoice (verified by the seller, but also by the buyer (reference stamp)). Instead of the invoice verified by the buyer, as proof of the origination of receivables, one may use the packing list (verified by the buyer), bearing the date of goods reception, or a written confirmation of the buyer that the goods were received. This eliminates the so-called performance risk, i.e. the risk of production and shipment of adequate goods. The value of advance payment will, before disbursement, be reduced by the application processing fee, factoring fees and interest (calculated in respect of the approved, i.e. agreed advance, in line with the duration of the factoring transaction). In certain cases, it is possible to arrange the payment of interest in line with the collection of receivables. In case of a collection of the full $100 \%$ amount of the invoice, the bank (factor) transfers to the client's account the remaining $30 \%, 20 \%$, or $10 \%$. The bank (factor) transfers the remaining amount, but is not held accountable for it, because it is a part of the receivables transferred from the seller to the factor, and not the part of the purchased receivables (purchased receivables are equal to the amount of disbursed amount). The remaining amount can also be referred to as the guarantee fund (factoring reserve). The guarantee fund represents the share of the client (seller) in the transaction risk. The disbursement of $100 \%$ of the invoice deduced by fees and interest is effected only exceptionally, when the transaction risk is really low (factoring with recourse; extremely strong company on the side of the seller, but also the buyer, in terms of its financial and market position; long-term, successful history of cooperation between the buyer and seller without any complaints; additional collateral, etc.). The assets within the guarantee fund are directly proportionate to transaction risk, buyer's risk, country risk in case of export factoring, concentration risk on the side of buyers (factoring with one buyer or several buyers), type of factoring, etc. The amount of the advance, and the guarantee fund, also depends on the parameters characterizing the quality of historical cooperation between sellers and buyers, based on the available information obtained from the seller. One of the most important parameters relates to the potential disputes concerning the quality of shipments and the amount of goods that the buyers used in order to effectuate the payment of a smaller amount compared to the nominal value of the invoice (complaints). What is also important are historical data related to the breach of payment deadlines, results of the analysis of buyer-seller contracts (existence of potential discounts, i.e. discounts for advance payments or certain amounts of shipment), along with potential historical settlements of payables by means of compensations (compensation-based settlement of receivables and payables reduces the potential for factoring). It is necessary for each contract subject to factoring, but also for each invoice, to unambiguously indicate that compensation is not allowed.

Receivables are transferred from the seller to the factor after a factoring agreement gets signed. The Law on Factoring prescribes that a factoring agreement shall contain the elements of an agreement of cession, hence it is sufficient in terms of receivables transfer. In order for a transfer of receivables to be legally binding, there must be a proof that the buyer was duly notified about the transfer of receivables to the factor. If the concerned notification was sent pursuant to the instruction prescribed by the Law on Factoring (it must contain information about the factoring agreement, data on factoring, 
robe koja se finansira, tj. novca koji je prati. Transakcija je bazirana na obezbeđenju i izolaciji novčanog toka, tj. na strukturi transakcije, a ne na rejtingu odnosno kreditnom bonitetu klijenta. U najvećem broju slučajeva transakcija se realizuje preko za tu svrhu novoosnovane kompanije (special purpose vehicle). Takođe, u najvećem broju slučajeva ino-banka finansira lokalnog klijenta, a u tome ima pomoć povezanog pravnog lica - banke na lokalnom tržištu. Predmet finansiranja je berzanska roba (nafta, bakar, aluminijum, ugalj, platina, srebro, žitarice, itd.), koja ima izraženu promenljivost cena, te je s toga i sama transakcija rizičnija. Usled toga, pored obezbeđenja u vidu zaloge na zalihama i potraživanjima, u Evropi se zahteva i osiguranje od promene cena sirovina. Drugačiji način zaštite jeste korišćenje "forward", „futures“ i drugih aranžmana. Ostali rizici koji se javljaju kao deo transakcionog rizika su: rizik proizvodnje, transporta, kupca, zemlje prodavca, zemlje kupca, itd. Pitanje da li će dužnik vratiti kredit, preformulisano je pitanjem da li će dužnik proizvesti (rizik izvršenja)? Veoma važan deo transakcija jeste i osiguranje potraživanja u slučaju bankrotstva (nelikvidnosti) kupca, a u određenim slučajevima se zahteva i osiguranje od rizika zemlje za slučaj zabrane izvoza robe koja je finansirana. Svaki aranžman je krojen potrebama klijenta i same transakcije, te ne postoji matrica načina rada na pojedinačnoj transakciji (svaki slučaj je jedinstven). Analizira se transakcija koja se finansira, proces proizvodnje, mogućnost adekvatne isporuke, svi kupci koji učestvuju u procesu (izvor otplate).

\section{Proizvodi pod okriljem strukturnog finansiranja trgovine}

- finansiranje na bazi skladišnica - modalitet objašnjen u odeljku finansiranja faze poslovanja pre isporuke, $u z$ razliku $u$ tome što je finansiranje obezbeđeno inokreditnom linijom od matične banke, a lokalna banka kontroliše proces upisa instrumenata obezbeđenja i indosiranja skladišnica u svoju korist. ${ }^{17}$

- finansiranje na bazi odnosa vrednosti obrtne imovine $i$ plasiranog kredita (borrowing base financing) - lokalna banka zajedno sa monitoring agencijom kontroliše izveštaje koje na nedeljnoj osnovi dostavlja klijent, a po pitanju obrtne imovine koja je založena kod banke, kao i po pitanju nove imovine - novi prilivi, nova roba - zalihe, novi kupci - ugovori o izvozu itd. Banka i monitoring agencija vrše proveru izveštaja, uspostavlja se dodatna zaloga ili je to već obuhvaćeno postojećom i sagledava se zahtevani odnos vrednosti zaloge nad obrtnom imovinom i kredita (raspon od 130\% do 150\%). Ukoliko u tom odnosu postoji dodatni prostor vrši se transfer sredstava ka klijentu do gornjeg limita.

- finansiranje proizvodnje klijentu koji ne poseduje proizvodne kapacitete (tolling/ processing) - finansiranje naknade za proizvodnju, troškove pakovanja, isporuka, itd., klijentu koji sirovine predaje drugoj firmi kako bi ista proizvela konačan proizvod. Klijent to čini jer nema sopstvene kapacitete. $S$ druge strane putem ovog tipa finansiranja moguće je finansirati nabavku sirovina koja se dostavlja proizvođaču na proizvodnju konačnog proizvoda (kupacnema kapacitete). Podrazumeva finansiranje procesa konverzije sirovine u poluproizvod ili gotov proizvod, a radi dobijanja proizvoda veće vrednosti od vrednosti sirovine. Najvažnija je analiza tržišta, a u smislu mogućnosti brze realizacije takvog proizvoda. Veoma često se zahteva unapred potpisan ugovor o prodaji proizvoda poznatom kupcu koji svojim finansijskim stanjem garantuje mogućnost realizacije. Dakle, analizira se vlasnik sirovine i njegova pouzdanost, proizvođač - njegova pouzdanost da proizvede, tržište i krajnji kupac. Dobavljač zadržava vlasništvo nad robom - sirovinom (najčesće prethodno založeno u korist banke) i preuzima robu - tj. gotove proizvode na bazi robe koju je dopremio do fabrike. Za tu uslugu preduzeće plaća proizvođaču određenu naknadu. U najvećem broju slučajeva vrednost zaliha je višestruko veća od vrednosti proizvodnje odnosno naknade koja se plaća za proizvodnju, te je i to jedan od faktora umanjenja rizika transakcije.

- finansiranje kupovine (uvoza) avansnim

17 Youssef, Frida, finance and energy unit, UNCTAD, “Commodity finance and risk management", 2010, p. 6 
the entity to whom the debtor is obliged to pay, and relevant payment instructions $)^{15}$, the buyer is legally obliged to effect a payment into the factor's account instead of into the seller's account. With a view to mitigating transaction risk, most factors in the domestic market require from the buyer to verify the notification, and to issue a statement, confirming that he received the concerned goods, i.e. services, and that upon maturity he will effect the payment to the factor, according to the instruction submitted in the notification. The invoices subject to the purchase in the form of factoring transaction must be acceptable for the factor. The invoices must bear the reference stamp of the debtor (buyer), or otherwise, a different proof indicating that the goods were received. The minimum qualitative requirements include the following: indicated payment deadline; indicated type and amount of products; invoices subject to the purchase must not contain any clauses forbidding the transfer of receivables; they must precisely state the amount of all potential discounts to the benefit of debtors (advance-based discounts, amount-based discounts, etc.); the invoices or other documents must indicate that compensations are not allowed.

\section{Forfeiting}

Forfeiting is a purchase of long-term, undisputed, matured, and transferrable receivables. Forfeiting is based on a purchase without recourse against the seller. Participants in forfeiting are the following: domestic exporter (manufacturer - seller), foreign importer, bank (forfeiter) ${ }^{16}$. The forfeiting agreement is not regulated by comparative law, as is the case with other agreements in the field of commercial trade - instead, it is a product of banking and commercial practice. Operations in respect of which forfeiting can be used include: large, oneoff deliveries of equipment, turnkey real estate construction projects, investment works with deferred payment deadline ranging from one to several years.

\section{Structured trade finance}

Structured trade finance is a type of finance from foreign sources (cross-border), targeted at developing markets, and focused on the transaction liquidating, i.e. repaying itself based on the movements of the financed goods, i.e. the underlying cash. The transaction is based on securing and isolating the cash flow, or in other words, on the structure of the transaction, instead of on the client's rating, i.e. creditworthiness. In the majority of cases the transaction is implemented through the newlyestablished company (the so-called Special Purpose Vehicle). Moreover, in most cases the foreign bank finances a local client, with the help of an affiliated legal entity - bank on the local market. The subject of finance are exchange commodities (oil, copper, aluminium, coal, platinum, silver, crops, etc.), whose prices are highly volatile, thereby making the transaction riskier. Thus, in addition to collateral in the form of a pledge on inventories and receivables, what is required in Europe is insurance against the changes in raw materials' prices. Another method of protection is usage of forwards, futures, and other similar arrangements. Other risks occurring as part of transaction risk are: production risk, transport risk, buyer's risk, seller's country risk, buyer's country risk, etc. The question of whether the debtor will repay the loan has been replaced by the question of whether the debtor will produce the goods (performance risk). An extremely important segment of transactions is the insurance of receivables against the bankruptcy (illiquidity) of the buyer, and in certain cases it is also required to have the insurance against country risk, in the event of the financed goods being banned for export. Each arrangement is tailored to meet the needs of the client and the transaction itself, hence there is no methodological matrix for individual transactions (each case is unique). What has to be analyzed is the financed transaction, production process, possibility of adequate delivery, all buyers participating in the process (source of repayment). 
plaćanjem (pre-export (prepayment) finance) finansiranje kupovine robe od ino-prodavca koji robu skladišti u ovlašćenom skladištu uz postojanje skladišnica koje predstavljaju dokaz vlasništva nad robom. Kupovina robe se vrši plaćanjem unapred - avansno. Kupac dobija kredit i plaća avansno izvozniku. Suština je u tome da je izvoznik robu držao deponovanu u sertifikovanom skladištu i da je prodao, tj. indosirao skladišnicu na kupca čime je kupac stekao vlasništvo nad robom. Dakle, vrši se razmena novca za skladišnicu. To pravo se reguliše i u ugovoru koji uz skladišnicu predstavlja osnov za uspostavljanje zaloge u korist banke. Na taj način se eliminiše rizik kvaliteta isporučene robe jer se isti može proveriti pre plaćanja, kontrolom robe u skladištu. Takođe, eliminiše se i rizik isporuke kako sa stanovišta vremena, tako i sa stanovišta konačne proizvodnje, pa i bankrotstva proizvođača. Postoje veliki rizici ovakve transakcije is toga uloga lokalne banke dolazi do izražaja, a u smislu sagledavanja barijera u domaćem zakonodavstvu. Pitanja koja se postavljaju su: da li će kupac zaista imati vlasništvo nad robom, da li to što prodavac nije platio obaveze prema državi ometa promenu vlasništva nad robom, da li je neophodna saglasnost vlade ili centralne banke? ${ }^{18}$

- finansiranje bazirano na budućim potraživanjima $i$ zalihama (export receivables-backed finance) - finansiranje kupovine robe od domaćih i/ili inoprodavaca, uz uspostavljanje zaloge nad obrtnom imovinom (robom i potraživanjima koji će nastati kao posledica finansiranja), radi prodaje domaćim i/ili ino-kupcima uz njihovo obavezivanje da dug izmire plaćanjem na račun lokalne banke. Teži se izolaciji novčanog toka, te se zahteva osnivanje potpuno nove firme kao nosioca kredita. $^{19}$

\section{Primer transakcije strukturnog finansiranja trgovine}

Opis preduzeća: U transakciji koju uzimamo za primer posmatramo način finansiranja nabavke sirovine za proizvođača utrživog proizvoda. U pitanju je klijent koji ima višedecenijsko iskustvo u kapitalno-intenzivnoj industriji zasnovanoj na proizvodnji korišćenjem sirovina berzanskog karaktera. Klijent ima više-decenijske poslovne partnere (kupce i dobavljače) u zemlji i inostranstvu. Pored dugoročnih kupaca koji usled kvalitetne istorije poslovanja (brze, precizne i kvalitetne isporuke) žele da očuvaju postojeći lanac snabdevanja, pojavljuju se i novi kupci koji žele da započnu saradnju sa klijentom. Prodaja je usmerena na izvoz koji u ukupnim prihodima učestvuje sa preko $85 \%$. Generalno, radi se o preduzeću koje spada u najveće izvoznike i koje je po količini proizvoda na godišnjoj osnovi tržišni lider. Preduzeće ima odlične odnose sa dobavljačima, koji uprkos krizi pružaju mogućnost delimičnog odloženog plaćanja (50\% avansno, 50\% do 45 dana). Sirovina se dominantno obezbeđuje na domaćem tržištu, tako da sa stanovišta uvozno-izvoznih aktivnosti klijent nije izložen valutnom riziku. Klijent ima konkurentne proizvodne kapacitete. Takođe, konkurentska prednost $\mathrm{u}$ odnosu na velike evropske kompanije jeste mogućnost proizvodnje većeg opsega proizvoda i uzimanje u obradu manjih zahteva. Velike kompanije usled masivnih kapaciteta i robusne proizvodnje to nisu u mogućnosti da pruže (veoma visoki fiksni troškovi preusmeravanja na drugi proizvod), već prihvataju isključivo velike narudžbine sa tržišta. Druga velika prednost jeste zaokružen poslovni proces bez potrebe angažovanja podizvođača.

Uzrok krize i zahteva za finansiranjem: Preduzeće je prošlo kroz teške periode i ispoljava loše finansijske pokazatelje koji uzrokuju loš kreditni rejting. Recesioni period je uzrokovao značajne turbulencije cena osnovne sirovine. Neadekvatno upravljanje zalihama je uticalo na gomilanje istih, tj. povećanje troškova finansiranja obrtnog kapitala. Takođe, uticalo je i na cenovni rizik. Pored aspekta upravljanja zalihama, primetan je i aspekt visokog zaduživanja u prošlosti. Pasiva bilansa stanja

18 Youssef,Frida, finance and energy unit, UNCTAD, "Structured trade finance, and its reference to emerging markets", Yerevan, 13 November 2003, p. 15

19 Youssef, Frida, finance and energy unit, UNCTAD, “Commodity finance and risk management", 2010, p. 8 


\section{Products within structured trade finance}

\section{- Finance based on warehouse certificates - A} modality explained in the section dealing with pre-shipment finance, the difference being that the finance is backed by a crossborder credit line of the parent bank, while the local bank controls the process of registering collaterals and endorsing warehouse certificates in its favor ${ }^{17}$.

\section{- Finance based on the ratio of working assets'} value and granted loan's value (borrowing base financing) - The local bank, together with the monitoring agency, controls the reports submitted by the client on a weekly basis, concerning the working assets pledged with the bank, and concerning new assets - new inflows, new goods - inventories, new buyers - export agreements, etc. The bank and the monitoring agency control the reports, register additional pledges if it has not been covered by the existing one, and consider the required ratio of the working assets pledge value, and the loan value (ranging from 130\% to $150 \%$ ). If there is additional room in respect of this ratio, the funds are transferred to the client up to the upper limit.

- Financing the production of a client without any production capacities (tolling/processing) - Financing the fees for production, packaging costs, shipment, etc. of a client who submits raw materials to another firm so that it could manufacture the final product. The client does so because he has no production capacities of his own. On the other hand, by means of this type of finance it is possible to finance the procurement of raw materials to be submitted to the manufacturer so that he could manufacture the final product (the buyer has no required capacities). This implies financing the process of converting raw materials into half-products or final products, with a view to obtaining products of higher value than the value of raw materials. The most important thing here is market analysis, in terms of possibilities for fast realization of such a product. It is frequently required to have a previously signed agreement on selling the products to a familiar buyer, whose financial position guarantees the possibility of realization. The analysis, therefore, covers the owner of raw materials - and his reliability; the manufacturer - and his reliability to manufacture; the market and the ultimate buyer. The supplier keeps his ownership over goods - raw materials (typically pledged beforehand to the benefit of the bank) and takes over the goods - i.e. final products based on the goods he shipped to the factory. For this service the company pays a certain fee to the manufacturer. In the majority of cases the value of inventories is many times higher than the value of production, i.e. the fee paid for that production, which is another factor mitigating the transaction risk.

- Financing the purchase (import) by means of advance payment (pre-export (prepayment) finance) - Financing the purchase of goods from a foreign seller storing his goods in a certified warehouse, with warehouse certificates serving as proof of ownership. The goods are purchased by means of advance payment. The buyer gets a loan and effects an advance payment to the exporter. The essence is that the exporter held his goods stored in a certified warehouse, and that he sold, i.e. endorsed the warehouse certificate to the buyer, whereby the buyer acquired ownership over the concerned goods. In other words, money is exchanged for the warehouse certificate. This right also gets regulated by the agreement which, in addition to the warehouse certificate, represents the foundation for establishing a pledge to the benefit of the bank. This eliminates the risk of delivered goods' quality, because it can be checked before payment, by controlling the goods in the warehouse. Moreover, this also eliminates the risk of delivery in terms of deadlines, in terms of final production, and in terms of the manufacturer's bankruptcy. Such a transaction incurs huge risks, which is why the role of the local bank becomes prominent, when it comes to considering the barriers in the local legislation. The questions raised are the following: will the buyer actually 
ukazuje na rast obaveza iz godine u godinu ali pozitivan efekat nije vidljiv kroz porast prihoda ili kapitala, niti kroz porast imovine ili smanjenje obaveza. Volumen zaduživanja nije usmeravan $\mathrm{u}$ operativno poslovanje, pri čemu je crpeo profitni potencijal poslovanja, što je uz izvlačenje kapitala (pozajmljenog kroz kredite, ali i do tada akumuliranog) od strane prethodnih vlasnika (promenjena vlasnička struktura) dovelo preduzeće $u$ situaciju da $\mathrm{mu}$ je neophodno značajno srednjoročno finansiranje kako bi ponovo pokrenulo poslovanje. Srednjoročno finansiranje je neophodno jer preduzeće beleži pad nivoa zaliha ispod nivoa neophodnog za minimalno, egzistencijalno poslovanje. Drugim rečima preduzeću je neophodan kredit za finansiranje trajnih obrtnih sredstava. Ipak, imajući u vidu narušenost finansijskih izveštaja, nemoguće je obezbediti klasičnu, srednjoročnu kreditnu liniju na lokalnom tržištu.

Struktura transakcije: Na ovom primeru se prepoznaje zastarelost tradicionalne kreditne podrške. Ipak, jedna od mogućnosti je finansiranje kroz strukturno finansiranje trgovine (podrškom ino-banke), tj. kroz izolaciju budućeg novčanog toka od prodaje finansiranih proizvoda čime bi se stvorila sigurnost povrata kredita. Dakle, fokus je na tome kako izolovati novčani tok i kako ga zaštiti od blokade tekućeg računa (pritisak poverilaca), ali i nenamenske upotrebe priliva. Naravno, najsigurnija opcija bi bila finansiranje preko potpuno nove firme osnovane od strane preduzeća u fokusu i obezbeđenje njegovog jemstva. Ta struktura bi podrazumevala mnogo bolju kontrolu novčanog toka, a eventualna blokada tekućeg računa bila bi izbegnuta kroz kontrolu novog preduzeća koje je bez obaveza. Zalihe koje bi na ovaj način bile kupljene morale bi da budu založene $u$ korist lokalne banke kao deo ukupnih instrumenata obezbeđenja. $S$ druge strane sva potraživanja koja bi potekla iz transakcije od strane domaćih i dominantno ino-kupaca, bila bi takođe založena u korist lokalne banke. Kredit bi počivao na tzv. „borrowing base“ principu, što znači da bi u svakom trenutku odnos zaliha i potraživanja u odnosu na sredstva kredita u korišćenju morao da bude minimalno $100 \%$ : $70 \%$. Dakle, postojala bi mogućnost puštanja kredita u tranšama, a prema stanju i vrednosti obezbeđenja. Angažovala bi se eksterna proceniteljska kuća koja bi kontrolisala i prosleđivala nedeljne izveštaje o stanju i vrednosti zaliha na skladištu. Na osnovu izveštaja vršila bi se analiza mogućnosti plasiranja novih sredstava. Kao dodatni vid obezbeđenja koristilo bi se osiguranje potraživanja od bankrota inokupaca i vinkulacija (prenos) polisa na banku kreditora. Ukupna potraživanja morala bi biti osigurana do $90 \%$ vrednosti, od strane prihvatljive i renomirane osiguravajuće kuće („Euler Hermes“ na primer). Takođe, svaka faktura povodom isporuke bi nosila račun lokalne banke na koji bi sredstva bila uplaćivana. Budući da postoje domaći i inokupci otvorila bi se dva računa u okviru lokalne banke, koji bi bili namenski (escrow) računi (zaštićeni od potencijalne blokade) i nad kojima bi bila uspostavljena zaloga (u slučaju stečaja banka bi sredstva mogla da koristi da namiri svoja potraživanja). Dakle postojao bi krug u okviru koga bi sredstva cirkulirala. Taj krug bi morao da ima neku vrstu zaštite tj. izolacije. Sredstva bi se kretala od ino-banke ka lokalnoj banci (local agent) koja bi kontrolisala puštanje sredstava ka dobavljačima. Potom bi sredstva po svim isporukama ka domaćim i ino-partnerima bila usmeravana na račun lokalne banke koja bi po osnovu ino-kredita sredstva usmeravala matičnoj banci, tj. inokreditoru. Dodatni uslov transakcije bi bio uvođenje kvalitetnijeg sistema kontrole zaliha (usaglašavanje vremena narudžbina sa izveštajima o gotovim proizvodima za isporuku), radi smanjenja vremena vezivanja istih u preduzeću, a u cilju maksimiziranja potencijala obrtnog kapitala. U prethodnom periodu cena osnovne sirovine je bila veoma promenljiva, a gomilanje zaliha je dovodilo do velikog cenovnog rizika. Imajući to u vidu, politika nabavke zaliha koliko proizvodni proces i tržište mogu da apsorbuju, uzrokovala bi smanjenje troškova obrtnog kapitala, ali i zaštitu od cenovnog rizika. Lokalna banka kod predmetnih transakcija mora da ukaže na rizike koji se pojavljuju u okviru njene nadležnosti, da obezbedi upis svih instrumenata obezbeđenja, ali i prijem sredstava i transfer ka dobavljačima (kontrola korišćenja sredstava). 
acquire the ownership of the goods; does the fact that the seller did not settle his liabilities towards the state hinder the transfer of ownership of goods; is it required to obtain the consent of the government or the central bank? ${ }^{18}$

- Finance based on future receivables and inventories (export receivables-backed finance) - Financing of the purchase of goods from domestic and/or foreign sellers, with the establishment of a pledge over the working assets (goods and receivables occurring as a result of the finance), with the purpose of selling to domestic and/or foreign buyers, after they commit to settling the debt by effecting a payment into the local bank's account. The idea is to isolate the cash flow, hence it is required to establish a completely new firm as the loan beneficiary ${ }^{19}$.

\section{Example of a structured trade finance transaction}

Company description: In the transaction that we hereby state as the example, we observe the method of finance of the raw material procurement for the manufacturer of a marketable product. This is a client with several decades of experience in a capital-intense industry based on the production through utilizing raw materials that are exchange commodities. The client has several-decade long relationships with his business partners (buyers and sellers), both in the country and abroad. In addition to the long-term buyers who, due to the good-quality history of doing business (quick, precise and sound delivery), wish to preserve the existing supply chain, the new buyers appear, wishing to launch cooperation with the client. The sales are directed to exports, which account for over $85 \%$ of total revenues. In general, this is a company which belongs to the category of top exporters, and which is the market leader according to the volume of products at the annual basis. The company has established excellent relations with its suppliers, who, despite the crisis, offer the possibility of partial deferred payment (50\% in advance, $50 \%$ up to 45 days). The raw materials are predominantly provided from the domestic market, so that, in terms of export-import activities, the client is not exposed to currency risk. The client has competitive production capacities. Also, what gives it competitive advantage compared to large European companies is the possibility to manufacture larger volume of products, and process smaller requests. Due to their mass-scale capacities and robust production, big companies are unable to provide this (extremely high fixed costs and redirections to other products), which is why they exclusively accept large orders from the market. Another substantial advantage is the rounded-up business process without any necessity to hire subcontractors.

Cause of the crisis and finance request: The company has suffered some difficult periods and has been recording poor financial indicators, reflected in a poor credit rating. The recession period has caused significant turbulences in the prices of raw materials. The inadequate management of inventories has resulted in their accumulation, entailing the increased costs of working capital financing. It has also affected the price risk. In addition to the aspect of inventories management, what has been observed is the aspect of excessive borrowing in the past. The liabilities in the balance sheet indicate a growth of payables on a year-to-year basis, while at the same time there have been no visible positive effects in the form of increased revenue or capital, or through growth of assets or reduction of liabilities. The volume of borrowing was not directed into operational business, exhausting the business profit potential instead, which, in combination with the withdrawal of capital (borrowed in form of loans, but accumulated until then) by the previous owners (changed ownership structure) brought the company in the position of needing substantial medium-term finance in order to re-launch its operations. Medium-term finance is required because the company has recorded a drop in inventories below the level necessary for minimal, existential operations.

18 Youssef, Frida, finance and energy unit, UNCTAD, “Structured trade finance, and its reference to emerging markets", Yerevan, 13 November 2003, p. 15

19 Youssef, Frida, finance and energy unit, UNCTAD, “Commodity finance and risk management", 2010, p. 8 


\section{Troškovi finansiranja obrtnog kapitala i uticaj proizvoda finansiranja lanca snabdevanja na smanjenje istih}

Apsolutni troškovi finansiranja obrtnog kapitala direktno su povezani sa količinom potrebne obrtne imovine za projektovanu poslovnu strategiju (održavanje tržišne pozicije ili pak rast obima poslovanja) i troškovima kratkoročnog finansiranja iste (eksterni ili sopstveni izvori). Ukoliko je ciklus gotovine kraći firma bolje upravlja obrtnim kapitalom, a ukoliko je duži firma lošije upravlja tj. više novca je vezano u procesu nabavke, proizvodnje, isporuke i naplate, a to iziskuje potrebu za dodatnim finansiranjem operativnog poslovanja ili likvidnosti. Tehnika finansiranja lanca snabdevanja sa stanovišta elemenata ciklusa gotovine pomaže u skladu sa činjenicom da obrnuti faktoring može da utiče na produženje roka plaćanja kupca, a istovremeno da skrati rok naplate prodavcu. $S$ druge strane faktoring doprinosi naplati pre roka dospeća, a to isto proizvodi i diskontovanje akreditiva, itd. Tehnika finansiranja lanca snabdevanja sa stanovišta troškova finansiranja pomaže u smislu da su ovi proizvodi u razvijenim zemljama Evrope cenovno konkurentniji od kreditiranja - faktoring ima manji stepen loših plasmana te je i cena niža, kod obrnutog faktoringa cena kreditiranja dobavljača lošijeg rejtinga se bazira na jakom kupcu, a finansiranje na bazi diskontovanja akreditiva ili pak BPO-a dovodi do formiranja cene na rejtingu banke izdavaoca. 
In other words, the company needs a loan to finance its permanent working capital. Nevertheless, bearing in mind the unreliability of its financial statements, it is impossible to provide a classic, medium-term credit line at the local market.

Structure of the transaction: This example illustrates the obsoleteness of traditional credit support. Nonetheless, one of the options is financing in the form of structured trade finance (through the support of a foreign bank), i.e. by isolating the future cash flow from the sales of financed products, which would generate the security of loan repayment. So, the focus is on how to isolate the cash flow, and how to protect is from the current account blockade (pressure on the part of creditors), but also from the improper utilization of inflows. Of course, the safest option would be the financing through a completely new firm, established by the concerned company, and the procurement of its pledge. Such a structure would imply a much better control of cash flows, and the potential current account blockade would be avoided due to the control of the newly-established firm, having no payables. Any inventories purchased this way would have to be pledged to the benefit of the local bank, as part of the total collateral. On the other hand, all receivables arising from the transaction by domestic and, dominantly, foreign buyers, would also be pledged to the benefit of the local bank. The loan would be resting on the so-called borrowing-base principle, which means that, at any moment, the ratio of inventories and receivables against the utilized loan funds would have to be at least $100 \%$ : $70 \%$. Thus, it would be possible to release the loan in tranches, in line with the state and value of collateral. An external evaluation agency would be hired to control and submit weekly reports about the state and value of inventories in the warehouse. Based on these reports, the relevant analysis would be conducted to define the possibilities of releasing new funds. As additional collateral, one would resort to insurance of receivables against the foreign buyers' bankruptcy and assignation (transfer) of premiums to the creditor's bank. Total receivables would have to be insured up to $90 \%$ of their value, by a recognized and reputable insurance company ("Euler Hermes", for instance). Moreover, each invoice in respect of delivery would feature the local bank's account into which the funds are to be paid. Given that there are both domestic and foreign buyers, two accounts would be opened at the local bank, as escrow accounts (protected from potential blockades) against which a pledge would be established (in case of bankruptcy the bank could use the funds to settle its receivables). In other words, there would be a circle within which the funds could circulate. This circle would have to have some sort of protection, i.e. isolation. The funds would be flowing from the foreign bank towards the local bank (local agent), which would then control the release of funds towards the suppliers. After that, the funds in respect of all deliveries to domestic and foreign partners would be directed into the local bank's account, which would then, in respect of foreign loans, direct the funds to the parent bank, i.e. foreign creditor. An additional condition for such transaction would be the introduction of a higher quality system of inventories control (harmonization of dates when orders were placed with the reports on final products ready for shipment), with a view to reducing the period of their being held at the company, and, in turn, maximizing the working capital potential. In the previous period the prices of raw materials were extremely volatile, and the accumulation of inventories incurred huge price risk. Bearing this in mind, the policy of inventories procurement, as much as the production process and the market can absorb, would cause a reduction in working capital costs, but also generate the protection against the price risk. When it comes to the concerned transactions, the local bank must indicate the risks occurring under its jurisdiction, register all collaterals, but also the reception of funds and their transfer to the suppliers (controlling the utilization of funds).

\section{Costs of working capital finance and the impact of supply chain finance products on their reduction}

The absolute costs of working capital finance are directly linked to the amount of working assets required for the projected business strategy (maintaining the market position or 


\section{Literatura / References}

1. McKinsey on Payments, "Supply chain finance: from myth to reality", October 2010, p. 24

2. Carswell, Kitt, Product Manager and Executive Consultant within CGI's Trade Services Group, "Supply Chain Finance: A new way for trade banks to strengthen customer relationships", 2007, p. 8, p. 10, p. 7, p. 9

3. Youssef, Frida, finance and energy unit, UNCTAD, "Structured trade finance, and its reference to emerging markets", Yerevan, 13 November 2003, p. 15

4. Ahmad, Munir \& Benson, Roger "Benchmarking in the Process Industries", IChemE, 2000 (izvor: http://www.clermiston. com.au/Supply\%20Chain. htm)

5. Regodić, Dušan, "Menadžment snabdevanjem", Univerzitet Singidunum, 2008, str. 37

6. Youssef, Frida, finance and energy unit, UNCTAD, "Commodity finance and risk management", 2010, p. 6, p. 8

7. Matić, Vesna, "Savremeni instrumenti finansiranja - forfeting", Bankarstvo, 3/4 2007, str. 74
8. Bryant, Charles and Camerinelli, Enrico, EBA (Euro Banking Association), "Supply chain finance", 2012, p. 18, p. 59

9. City Trade University, "SWIFT Net Trade Services helping banks meet the supply chain challenge", 2008, p. 11

10. International finance corporation, World Bank group, "Bank payment obligation: Financial instruments to manage risk in open account trade", 2013, p. 3

11. ICC (The World Business Organization), "2013 Rethinking trade \& finance", 2013, p. 52

12. International Chamber of Commerce, „,Bank payment obligation (managing risk, finance and processing efficiency for open account trade in a multi-bank environment) ", 2012, p. 3

13. Krasulja Dragan, Ivanišević Milorad: "Poslowne Finansije“, Ekonomski fakultet u Beogradu, 2001. godine, str. 437

14. Zakon o faktoringu („,Službeni glasnik RS“, broj 62/13) 
yet increasing the volume of business), and the costs of short-term financing of that strategy (external or own sources). If the cash cycle is shorter, the firm manages its working capital in a better way, and if it is longer, the firm manages it in poorer way, i.e. it has tied more cash in the process of procurement, production, delivery and collection, which generates the need for additional financing of operational activities or liquidity. The supply chain finance technique is helpful in terms of cash cycle elements, bearing in mind the fact that reverse factoring may influence the extension of the buyer's payment deadline, at the same time shortening the seller's collection deadline. On the other hand, factoring contributes to early (premature) collection, and the same effect is produced by $\mathrm{L} / \mathrm{C}$ discounting, etc. In terms of costs of finance, the supply chain finance technique is helpful because in the developed European countries the prices of these products are more competitive than crediting - in factoring there is a lower level of NPLs, hence the lower price; in reverse factoring the price of crediting a supplier with poorer rating is based on a strong buyer; whereas in finance based on $\mathrm{L} / \mathrm{C}$ discounting or BPO the price is formed based on the issuing bank's rating. 